The author(s) shown below used Federal funds provided by the U.S. Department of Justice and prepared the following final report:

Document Title:

A Multilevel Analysis of Juvenile Court

Processes: The Importance of Community Characteristics

Author:

Nancy Rodriguez

Document No.:

223465

Date Received:

July 2008

Award Number:

2006-IJ-CX-0016

This report has not been published by the U.S. Department of Justice. To provide better customer service, NCJRS has made this Federallyfunded grant final report available electronically in addition to traditional paper copies.

Opinions or points of view expressed are those of the author(s) and do not necessarily reflect the official position or policies of the U.S. Department of Justice. 


\section{A MULTILEVEL ANALYSIS OF JUVENILE COURT PROCESSES: \\ THE IMPORTANCE OF COMMUNITY CHARACTERISTICS}

Submitted to The National Institute of Justice

By:

Dr. Nancy Rodriguez

Arizona State University

June 30, 2008

This research was sponsored by the National Institute of Justice (2006-IJ-CX-0016). The opinions and conclusions expressed in this document are solely those of the author and do not necessarily reflect the views of the U.S. Department of Justice. 


\section{EXECUTIVE SUMMARY}

\section{Problem:}

Despite various federal and state legislation aimed at producing equitable treatment of juveniles within the juvenile court system, studies continue to find that race and ethnicity play a significant role in juvenile court outcomes. Juvenile court differences in philosophy, orientation, and structure make it possible for racial and ethnic disparities to exist within and between courts. Unfortunately, few studies of juvenile court processes have relied on cross-jurisdictional data to examine how court context influences juvenile court decisions and only one study to date has addressed how community characteristics where juveniles reside directly and indirectly impact juvenile court outcomes.

\section{Research Questions:}

The focus of this study is to conduct a multilevel analysis of juvenile court outcomes in Arizona. The study will examine how race/ethnicity and community disadvantage influence diversion, petition, detention, adjudication, and disposition decisions throughout the state. This study will also examine how juvenile court outcomes affect recidivism of juveniles post age 17.

\section{Methods and Research Design:}

A random sample of juvenile referrals to the Arizona juvenile courts during 2000 was drawn to conduct the study. Data for this project came from the three sources: 1) Arizona Juvenile OnLine Tracking System (JOLTS) database; 2) the Arizona Department of Public Safety; and 3) 2000 U.S. Census data.

\section{Findings:}

Analyses show that Blacks, Hispanic/Latinos, and American Indian juveniles were treated more severely in juvenile court outcomes than their White counterparts. Also, juveniles who were detained were more likely to have a petition filed, less likely to have petitions dismissed, and more likely to be removed from the home at disposition. A review of court context and community disadvantage revealed that juveniles from disadvantaged communities were treated more harshly than juveniles not from disadvantaged communities. Juvenile court actions (i.e., informal processing, detention, and out-of-home placement) were significant predictors of offending post page 17 . These findings are particularly relevant to state officials who are mandated to examine disproportionate minority contact (DMC) in their respective juvenile justice systems. Justice officials are encouraged to use the findings from this comprehensive review of juvenile court processes to change policies that may directly or indirectly disadvantage particular juveniles (e.g., racial/ethnic minorities, the poor). Developing procedures that provide equitable treatment to all juveniles and reduce the likelihood of continued criminality into adulthood need to be a central focus of the juvenile justice system. 


\section{A Multilevel Analysis of Juvenile Court Processes: The Importance of Community Characteristics}

Table of Contents

1. PURPOSE, GOALS, AND OBJECTIVES 2

2. REVIEW OF LITERATURE 4

a. Racial/ethnic Disparities in Juvenile Court Decisions 4

b. Cumulative Effects of Race/Ethnicity in Juvenile Court Outcomes 6

c. Court Context and Juvenile Court Decisions 6

$\begin{array}{ll}\text { d. Attribution Theory } & 8\end{array}$

e. Juvenile Court Actions and Reoffending 10

3. RESEARCH OBJECTIVES 11

5. RESEARCH DESIGN AND METHODS 13

a. Study Site $\quad 13$

b. Sample and Data 14

c. Variables $\quad 15$

1. Dependent Variables 15

2. Independent Variables 16

d. Methods of Statistical Analysis $\quad 17$

$\begin{array}{ll}\text { 6. FINDINGS } & 18\end{array}$

a. Descriptives 18

b. Racial/ethnic Disparities in Juvenile Court Outcomes 20

1. Informal Diversion 20

2. Detention 21

3. Petition Filed $\quad 22$

4. Dismissal of Petition 23

5. Out-of-Home Placement 23

c. The Relationship Between Juvenile Court Actions and Recidivism 24

7. DISCUSSION AND RESEARCH IMPICATIONS FOR POLICY AND PRACTICE

Appendixes

Appendix A. References

Appendix B. Tables 


\section{PURPOSE, GOALS, AND OBJECTIVES}

Racial/ethnic disparities in juvenile courts and recidivism among juvenile offenders are two of the most examined areas of the juvenile justice system. Prior studies have highlighted the role of community characteristics in juvenile court processes and outcomes, yet few have systematically included such measures in studies of racial and ethnic disparities. Engen, Steen, and Bridges (2002) note that a theoretical framework that highlights the role of race, ethnicity, and community variables can offer greater insight into the relationship between race/ethnicity and juvenile court outcomes. While researchers have examined the relationship between juvenile court processes and recidivism, recidivism in these studies is based on a limited measure of reoffending (i.e., offending of juveniles and not past age of maturity).

The purpose of this project is to develop a comprehensive multilevel analysis of juvenile court decision-making processes in Arizona. The goals of the project are 1) to establish how race and ethnicity influence diversion, petition, detention, adjudication, and disposition decisions; 2) to use multilevel data and identify the role of community characteristics in court outcomes; and 3) to establish how juvenile court outcomes affect juvenile offenders’ recidivism rates past age 17 .

A focus on racial/ethnic disparities that is sensitive to community dynamics can be of extreme value when attempting to identify and target system outcomes that lead to the disproportionate number of minority individuals in the juvenile justice system. As such, the following three research objectives are examined:

- Research Objective \#1: What is the relationship between the race/ethnicity of juveniles' and diversion, petition, detention, adjudication, and disposition outcomes? 
- $\quad$ Research Objective \#2: What is the relationship between community disadvantage and diversion, petition, detention, adjudication, and disposition outcomes?

- $\quad$ Research Objective \#3: What is the relationship between juvenile court outcomes and criminal behavior post age 17 ?

This study makes several contributions to the larger literature on juvenile court decisionmaking processes. Among those few prior studies of juvenile courts that have empirically measured court context, most have examined court characteristics using inappropriate analytical techniques. Unlike most prior work in this area, this study will rely on multilevel data to examine court decisions using the appropriate analytical strategies. Second, the setting for this study is Arizona which is characterized by a vastly growing racial and ethnic minority population. This setting facilitates a study of race and ethnicity and makes possible a focus on ethnic groups that have received minimal empirical focus (e.g., Hispanic/Latinos and American Indians) in studies of juvenile court decisions. Clearly, a study that examines how White, Black, Hispanic/Latino, and American Indian juveniles are processed within the juvenile court can provide a more "comprehensive representation" of racial and ethnic disparities in court decisions (Pope, Lovell, \& Hsia, 2002). Third, a multistage study of juvenile court processes that is able to identify how juvenile court outcomes affect future offending can direct the allocation of resources to better serve and reduce criminal offending among youthful offenders. 


\section{REVIEW OF LITERATURE}

Racial/ethnic Disparities in Juvenile Court Decisions

Studies of juvenile courts have found a direct and indirect relationship between race/ethnicity and juvenile court outcomes (Bishop \& Frazier, 1988; Bishop \& Frazier, 1996;

Bortner \& Reed, 1985; Frazier \& Bishop, 1985; Secret \& Johnson, 1997; Schutt \& Dannefer, 1988; Wordes, Bynum, \& Corley, 1994). Research suggests that minority juveniles are more likely to be arrested, referred, detained, adjudicated, and transferred to adult criminal court at higher rates than their White counterparts (Bishop \& Frazier, 1988; Snyder \& Sickmund, 1999). Pope, Lovell, and Hsia (2002) and Engen, Steen, and Bridges (2002) have conducted extensive reviews of prior studies of race effects in juvenile justice processes and outcomes and have found that the majority of studies show significantly large racial disparities net the effects of legal control variables. Previous studies have also found that race has an indirect effect in court outcomes whereby juvenile court outcomes are affected by neutral factors that are highly correlated with race (e.g., social class and family status) (Pope \& Feyerherm (1990). In some research, the effect of race in court outcomes is not constant. That is, racial disparities exist in some decision points yet not in others. For example, Dannefer and Schutt (1982) found that racial minorities were treated more severely than Whites by police yet the pattern of discrimination was reversed by judges at the disposition stage, where Blacks were treated more leniently than Whites. Leiber and Jamieson (1995) found racial disparities exist at diversion, petition, and initial appearance, yet do not exist in subsequent decisions such as adjudication or disposition. Also, Guevara and colleagues (2006) found that although non-White males were more likely than other offenders (non-White females, white males) to be detained prior to adjudication, non-White males were less likely than other offenders to be ordered to an out-of- 
home placement. In an attempt to explain the varying effect of race across multiple decisions, Dannefer and Schutt (1982) propose that a correction of bias takes place whereby court officials attempted to counter the racial disparities produced by aggressive law enforcement strategies.

A review of research of racial disparities in juvenile courts reveals that the majority of studies rely on comparisons of White and Black juveniles. Further, the racial disparities occur in multiple decision points. For example, Bishop and Frazier (1988) found that Blacks were more likely to be formally processed, referred to court, adjudicated delinquent, and received more severe dispositions than White juveniles. Similarly, Pope and Feyerherm (1990) found that Black youth received more severe court outcomes than White youth, and that racial disparity occurred at various stages of juvenile court processing. Studies that have included several racial and ethnic groups show that Hispanic/Latinos are treated more harshly than Whites and Blacks (Maupin \& Bond-Maupin, 1999; Dannefer \& Schutt, 1982; DeJong \& Jackson, 1998) and American Indians receive more severe treatment than Blacks (Leiber, 1994).

In addition to race/ethnicity, other extralegal variables have been reported to impact juvenile court processing. For example, Bridges, Conley, Beretta, Engen, Price-Spratlen, Rankin, et al. (1993) found that juvenile offenders who were attending school and had families displaying some interest in juvenile offenders' cases (e.g., attended hearings) were less likely to be detained. Studies have also shown that legal factors such as offense seriousness, prior record, and probation violations are stronger predictors of detention status and prosecutorial referral than race (Bishop \& Frazier, 1996; Bishop \& Frazier, 1988; O’Neil, 2002; Hindelang, 1978; Gottfredson \& Hirschi, 1990; Lynch, 2002). 


\section{Cumulative Effects of Race/Ethnicity in Juvenile Court Outcomes}

Research capturing the direct and indirect effects of initial front-end decisions (e.g., referral, detention) has often referred to the "cumulative” effect of such decisions on back-end court processes (e.g., adjudication, disposition). The cumulative effect refers to race differences which appear in earlier stages of the juvenile court system and accumulate in back-end processes (Pope \& Feyerherm, 1990). As a result, race may indirectly influence later decisions due to biases in earlier decisions (e.g., detention) (Bortner \& Reed, 1985). Bishop and Frazier’s (1988, 1996) work has clearly shown the cumulative effect of differential treatment among minority populations in juvenile court processes.

Studies have found that racial disparity is most pronounced in the beginning stages of involvement with the juvenile court system, specifically the intake and detention decision points (Bishop \& Frazier, 1988, 1996; Bortner \& Reed, 1985; Leiber, 1994; Leiber \& Fox, 2005; Leiber \& Jamieson, 1995; Leiber \& Mack, 2003). In fact, research shows that being detained is a strong predictor of severe treatment at disposition (Bishop \& Frazier, 1988, 1992; Bortner \& Reed, 1985; Feld, 1993; Frazier \& Bishop, 1995; Johnson \& Secret, 1995; McCarthy \& Smith, 1986). For example, Frazier and Cochran (1986) found that Black youth were more likely than White youth to be detained and detention had a strong effect on subsequent case processing decisions. Recent work by Leiber and Fox (2005) highlights these results by detailing how the effects of detention work to disadvantage Black youth.

\section{Court Context and Juvenile Court Decisions}

Prior research has examined the impact of population density (e.g., urban versus rural jurisdictions) as well as specific measures of communities (e.g., poverty, racial/ethnic make-up) in juvenile court outcomes. A review of such studies shows that juvenile court outcomes are 
influenced by urbanism, racial inequality, economic factors, and crime rates (Armstrong \& Rodriguez, 2005; Bridges, et al., 1993; Feld, 1991; Frazier \& Lee, 1992; Sampson \& Laub, 1993; Secret \& Johnson, 1997; Wu, Cernkovich, \& Dunn, 1997). In his examination of detention practices in urban, suburban, and rural counties in Minnesota, Feld (1991) found that juvenile delinquents referred for person offenses and longer criminal histories were likely to be detained in all three types of counties. However, juvenile courts in urban counties had a higher rate of detention than the other counties and juveniles in urban courts were treated more severely than juveniles in rural or suburban courts. DeJong \& Jackson (1998) found that referral rates for Black and White juveniles were no different once controlling for population density. However, Hispanic juveniles were more likely than Whites to be referred once controlling for density and Hispanics were treated more harshly in rural than urban areas. The authors also found that while race/ethnicity did not affect placement decisions, there was a relationship between population density and placement decisions.

Feld (1991) suggests geographic differences in detention outcomes may be attributed to the varying social and economic environments in which courts reside. There has been support for this proposition in other studies. For example, Sampson and Laub (1993) found that Black juveniles were more likely to receive detention and out-of-home placements in counties characterized by poverty and racial inequality. Also, Frazier, Bishop, and Henretta (1992) examined 32 urban counties in Florida and found that percent White in the population was a significant predictor in dispositions of Black juveniles. Wu, Cernkovich, and Dunn (1997) used a sample of juvenile court data from nine counties in Ohio and found that urban counties, counties with higher proportions of White juvenile delinquents, and counties with greater income inequality were more likely to detain juveniles. Secret and Johnson (1997) examined the impact 
of individual and structural components in detention, adjudication, and disposition outcomes in

Nebraska and found that crime rate, percent high school education, percent unemployed, percent poverty, percent Non-White, percent urban, and percent average age significantly influenced juvenile court outcomes.

Prior studies have highlighted the significant role that poverty plays in juvenile crime and court outcomes. Juvenile offenders often live in impoverished communities characterized by a high percentage of families receiving public assistance, and female-headed households (Elliott, 1994; Emerson, 1969; Hawkins et al., 1998; Land, 2000). Interestingly, studies have found that White middle-class juveniles are far more likely to be processed informally than their Black lower-class counterparts (e.g., Miller, 1996; Sarri, 1983). Also, White and middle class juveniles are more likely to be filtered out of the system at earlier decision points than are poor and minority juveniles (Bishop \& Frazier, 1988). Bishop and Frazier (1996) suggest juveniles from lower class families may be processed formally through the court in order to receive the treatment they were unable to receive privately.

\section{Attribution Theory}

Attribution theory has been used to explain racial disparities in the justice system by noting the role that racial stereotypes play in court processing. Studies of criminal courts have addressed how attributions of criminal behavior are linked to racial/ethnic stereotypes (Albonetti, 1997; Bridges \& Steen, 1998; Crawford, Chiricos, \& Kleck, 1998; Steffensmeier \& Demuth, 2000; Steffensmeier, Ulmer, \& Kramer, 1998) and now a growing number of juvenile court studies are using this theoretical perspective to explain race/ethnicity disparities in juvenile court outcomes (Bortner, 1982; Bridges \& Steen, 1998; Dannefer \& Schutt, 1982; Leiber, 1994). Not surprisingly, the majority of studies have focused on the role of Black stereotypes in court 
processes and outcomes. For example, Leiber and Mack (2003) note that the more severe treatment of Blacks at disposition may be due to "stereotypical perceptions" held by court officials.

Researchers have suggested that citizenship status, language barriers, and possible unfamiliarity with the criminal justice system can lead to ethnic stereotypes that present Hispanic/Latinos as unresponsive to the justice system. These stereotypes or perceptions held by court officials can lead to more punitive treatment of Hispanics/Latinos (Brown \& Warner, 1992; Demuth, 2002; 2003; Portillos, 2002). Also, stereotypes of American Indians as “outsiders” and prone to drug and alcohol abuse may result in more severe treatment by the criminal justice system (Bachman, Alvarez, \& Perkins, 1996; Bynum \& Paternoster, 1984; Leiber, 1994; Young, 1990; Zatz, Lujan, \& Snyder-Joy, 1991).

Juvenile court studies have used attribution theory to examine the influence of internal and external attributes associated with racial/ethnic stereotypes. Bridges \& Steen (1998) found that both external (e.g., delinquent peers, poor school performance, family conflict) and internal (e.g., juvenile’s personality, attitude, and cooperativeness) attributions are linked to racial disparities. Specifically, court officials were more likely to assign negative internal attributions to Black youth and negative external attributions to White youth. Further, risk of reoffending and severity of disposition were influenced by negative internal attributes rather than external ones (Bridges \& Steen, 1998). Gaarder, Rodriguez, and Zatz (2004) found that attributes of delinquency and victimization assigned to girls by court officials were often linked to race, resulting in minimal efforts to address the histories of victimization and delinquency of some girls (e.g., Latinas). 
Although attributions related to delinquency have overwhelming focused on race and ethnicity, some studies highlight how court officials' perceptions of juveniles' communities play a role in decision-making processes. Emerson (1969) showed court officials’ perceptions of a “bad neighborhood” were used to make reference to juveniles’ levels of risk of reoffending. Like attributions that link race to delinquency and court outcomes, perceptions of socially disorganized communities may influence petition, detention, adjudication, and disposition rates for juveniles and result in more punitive treatment for juveniles who live in such communities (Bortner, 1982; Drass \& Spencer, 1987; Rodriguez, 2007). Bortner (1982) found that court officials often described the interrelationship between race and economic conditions of the family and the community. In particular, court officials related understanding why juveniles from impoverished communities "get in trouble" (Bortner, 1982, p. 154). Most recently, Rodriguez (2007) examined how juvenile court officials’ perceive environmental conditions (e.g., disadvantaged community) of juveniles and their relationship to juvenile court outcomes. By regarding community characteristics as external attributes, Rodriguez examined the impact of community disadvantage and crime on juvenile court outcomes and found that Hispanic/Latinos from economically advantaged and disadvantaged communities were treated more severely than their White counterparts.

\section{Juvenile Court Actions and Reoffending}

The extent to which juvenile court actions lead to reoffending has been the focus of several studies (Minor, Hartmann, \& Terry, 1997; Smith \& Paternoster, 1990; Wooldredge, 1988). The focus of this line of research has been on determining the extent to which specific court outcomes (e.g., diversion, detention, probation) influence recidivism among juvenile offenders. Wooldredge (1988) found that community supervision (i.e., probation) and treatment 
in the community lead to lower rates of recidivism among juveniles. Smith and Paternoster (1990) examined the impact of formal juvenile court processing in future delinquency and found that the relationship between referral to the court and recidivism could be explained by a selection artifact process. That is, juveniles referred to the court may posses more factors that are related to reoffending than juveniles not referred to the court. Minor, Hartmann, and Terry (1997) found no relationship between court action and future offending among a sample of 475 first time referrals to juvenile court. However, the authors did find that juveniles who were informally processed during their first referral to the court, were less likely to have an adult charge. To date, no study has examined the extent to which various juvenile court actions affect criminal activity in adulthood. In other words, it is unknown whether juveniles who are treated more or less punitively by the court are more likely to commit crime post age 17 .

\section{RESEARCH OBJECTIVES}

A theoretical focus on juveniles’ race and ethnicity (e.g., Whites, Blacks, Hispanic/Latinos, American Indians) and communities conditions can expand current knowledge of juvenile court decision-making processes. In order to capture the effects of race, ethnicity, and community characteristics in juvenile court outcomes, a multilevel analysis will be conducted. By relying on nested data (i.e., individual-level and zip code data), the following research objectives are examined.

- Research Objective \#1: What is the relationship between the race/ethnicity of juveniles’ and diversion, petition, detention, adjudication, and disposition outcomes?

- $\quad$ Research Objective \#2: What is the relationship between community disadvantage and diversion, petition, detention, adjudication, and disposition outcomes? 
- $\quad$ Research Objective \#3: What is the relationship between juvenile court outcomes and criminal behavior post age 17 ?

Studies of juvenile court decisions have primarily focused on the disparities that Blacks or non-Whites experience (Bridges \& Steen, 1998; Frazier \& Bishop, 1985; Leiber \& Jamieson, 1995; Sampson \& Laub, 1993). As previously shown, attributions can be linked to specific racial/ethnic groups and can affect offenders in different ways. For example, stereotypes unique to Blacks (Bridges \& Steen, 1998; Leiber \& Stairs, 1999; Sampson \& Laub, 1993), Hispanic/Latinos (Leiber, 1995; Mata \& Herrerías, 2002; Portes, 1990), and American Indians (Bynum \& Paternoster, 1984; Leiber, 1994; Young, 1990; Zatz, Lujan, \& Snyder-Joy, 1991) may lead to different juvenile court outcomes. The few studies that have examined how Hispanic/Latinos and American Indians are processed by the court relative to Blacks and Whites show that Hispanic/Latinos are treated more severely than Blacks and Whites (Maupin \& BondMaupin, 1999; Dannefer \& Schutt, 1982), while American Indians are treated less severely than Blacks (Leiber, 1994). A systematic study of juvenile court processes that includes White, Black, Hispanic/Latino, and American Indian juveniles will provide a comprehensive review of racial and ethnic disparities in juvenile court outcomes in one state. ${ }^{1}$

As previously discussed, prior studies have shown the significant role that community characteristics play in juvenile court decisions. It is therefore important to control for the community characteristics when conducting such studies. Court context and community characteristics may influence juvenile court decisions in important ways. Court officials may perceive certain communities as responsible for producing crime and unsuccessful at maintaining proper supervision and control (informal) of juveniles. In those instances, juveniles from

\footnotetext{
${ }^{1}$ Although an examination of the interaction between race/ethnicity and other factors (e.g., gender, offense type) on juvenile court outcomes is important, it is beyond the scope of this study.
} 
communities characterized by high levels of disorganization may receive more punitive treatment by the court than juveniles who do not reside in such communities.

While a few studies have examined how juvenile court processing impacts juvenile offending, none have systematically taken into account how various juvenile court outcomes influence adult offending. In order to examine how particular juvenile court outcomes (e.g., diversion, detention, and disposition) affect reoffending, this study will integrate statewide adult criminal history information to juvenile court data and examine how various juvenile court outcomes affect recidivism of juveniles post age 17.

\section{RESEARCH DESIGN AND METHODS}

In order to conduct a multilevel (i.e., individual, zip code) analysis of juvenile court processes and to examine how various court outcomes impact criminal offending post age 17, data from various sources were utilized. This project relied on data from three data sources: 1) the Arizona Juvenile On-Line Tracking System (JOLTS) database, 2) 2000 U.S. Census data, and 3) the Arizona Department of Public Safety.

Study Site

The setting for this study is Arizona which is characterized by a vastly growing racial and ethnic minority population. The setting facilitated a study of multiple racial and ethnic groups and more specifically, enabled a focus on ethnic groups that have received minimal empirical focus (e.g., Hispanic/Latinos and American Indians) in studies of juvenile court outcomes. Juvenile courts in two counties in Arizona (Maricopa and Pima Counties) have established Building Blocks Projects for Youth Initiatives (sponsored by the Youth Law Center, American Bar Association Juvenile Justice Center, W. Haywood Burns Institute, Juvenile Law Center, Justice Policy Institute, Minorities in Law Enforcement, National Council on Crime and 
Delinquency, and Pretrial Services Resource Center) aimed at reducing disproportionate minority contact (DMC) in the juvenile justice system. Pima County is also a site of the Annie E. Casey Foundation's Juvenile Detention Alternatives Initiative. These current efforts made Arizona an ideal setting for an examination of race/ethnicity and community characteristics in juvenile court outcomes.

\section{Sample and Data}

A random sample of juveniles referred $(\mathrm{N}=23,156)$ from all 15 counties in Arizona during 2000 was drawn from the JOLTS database to examine juvenile court decisions. ${ }^{2}$ Arizona’s Juvenile On-Line Tracking System (JOLTS) database captures information on juveniles’ court processing from the time the juvenile is referred to the juvenile court until court disposition. ${ }^{3}$ The unit of analysis for this study was the juvenile offender. In instances where a juvenile was referred to the court multiple times in 2000, the first referral in the year was included in the sample. Each juvenile was followed through five court outcomes: diversion, detention, petition, adjudication, and disposition. To examine the role of community disadvantage in juvenile court outcomes and to examine recidivism of juvenile offenders post age 17, JOLTS data was merged with 2000 Census data (Summary Tape File 1) and with Arizona’s Department of Public Safety data. The Arizona Department of Public Safety is responsible for maintaining all criminal history information (i.e., rap sheets) for the state. In order to obtain criminal history information, the principal investigator signed a Nondisclosure

\footnotetext{
${ }^{2}$ In order to ensure that juvenile court processes from each county in the state were included in the analyses, juveniles in rural counties were over sampled to ensure that at least 120 juveniles were included within each county. ${ }^{3}$ Cases excluded from the analysis include juveniles who were transferred to adult court, cases where there was a delay in the prosecution given juvenile's birthday (i.e., approaching 18 years old), cases transferred from one jurisdiction to another, terminated cases, fugitives, traffic violators, incorrigibility cases, and juveniles with a home address outside of Arizona.
} 
Agreement with the Arizona Department of Public Safety to receive approval to obtain electronic data on criminal histories for all offenders in the sample.

\section{Variables}

\section{Dependent Variables}

Multiple dependent variables were examined to reflect the multiple decision points in the juvenile justice system. Specifically, diversion (i.e., informally processed), detention, petition, adjudication, and disposition decisions were analyzed. Diversion (yes $=1$; no $=0$ ) occurs when the County Attorney makes the decision to not file a petition against the juvenile but rather place the juvenile into one of a number of diversion programs. If the juvenile complies with the program requirements, the County Attorney will not file charges against the juvenile. If the juvenile does not comply with the requirements, a filing of a petition alleging delinquency or incorrigibility could result. Detention (yes $=1$; no $=0$ ) was measured by comparing those juveniles who were detained at the detention advisory hearing with those not detained. ${ }^{4}$ The petition process occurs when the County Attorney files a petition against a juvenile alleging delinquency or incorrigibility (yes $=1$; no $=0$ ). For those juveniles who had a petition filed, during the adjudication process, the juvenile court judge determines whether to dismiss the petition(s) (yes = 1; no $=0$ ) or not (i.e., adjudicate the juvenile as delinquent or find him/her to be a status offender). For those juveniles that were found delinquent or as status offenders, the judge will order a type of disposition. An out-of-home placement measure (yes = 1; no =0) was used to represent those instances where offenders were ordered to the state juvenile correctional facility or not (i.e., community supervision - probation). In order to measure recidivism of

\footnotetext{
${ }^{4}$ Only juveniles who were formally processed (i.e., non-diversion cases) were examined in the detention, petition, adjudication, and disposition outcomes. Juveniles who were diverted could end up in detention or in other subsequent formal court processes if the juvenile failed to meet the diversion provisions. Since the focus of this study is not on the failure rate of diversion cases, subsequent court outcomes of these cases were not examined.
} 
juveniles post age 17, recidivism is measured for juveniles with criminal information reported to the Arizona Department of Public Safety up until July 31, $2007 .{ }^{5}$ Recidivism in this study included any arrest reported to any law enforcement agency in the state (yes $=1$; no $=0$ ). $\underline{\text { Independent Variables }}$

At the individual-level, both extralegal and legal variables were included in the analyses. Demographic indicators consisted of gender (boys= 1; girls=0), race/ethnicity (dummy coded variables for Hispanic/Latinos, Blacks, and American Indians with Whites as the omitted category), and age at time of court referral.

Legal variables included the most serious offense at referral (i.e., person felony, person misdemeanor, property felony, property misdemeanor, drugs, public peace, with property felony as the omitted category), and whether juveniles had prior referrals (yes $=1$; no $=0$ ). A control for school status (enrolled in school =1; not enrolled in school $=0$ ) at the time of court referral was also used. ${ }^{6}$ Analyses also included a dependency control measure that captured whether a dependency petition was filed before the (delinquent or status) referral (yes $=1$; no $=0$ ). In order to control for possible jurisdictional difference, population density was used to create a county-level measure, urban county (yes $=1$; no $=0$ ), for inclusion in the analyses. Consistent with prior work (Leiber \& Fox, 2005), a hazard rate variable was calculated and analyzed in the models to correct for possible sample selection bias (Berk, 1983). Given the critical role that detention plays in subsequent court outcomes, detention was a control measure in all analyses of subsequent juvenile court outcomes.

In order to control for community factors in juvenile court outcomes, a community-level measure was included in the analyses. By taking juveniles’ address at time of referral and

\footnotetext{
${ }^{5}$ Recidivism was only assessed for those juveniles who were formerly processed and reached age of maturity (i.e., 18 years old). The follow-up period included a three year period.

${ }^{6}$ Unfortunately, this study was unable to control for psychological risk factors.
} 
linking them to census zip code data from the 2000 Census (U.S. Bureau of the Census, 2000, Summary Tape File 1), a community disadvantage index was constructed using principal components analysis. ${ }^{7}$ Community-level variables used for the index included percent living in poverty, percent receiving public assistance, percent unemployed, percent with less than a high school education, and percent of female headed households with children under 18 years old. The eigenvalue for the factor was 3.76 with the factor dominated by high loading factors (> .80) with a slightly lower factor loading for percent of female headed households with children under 18 years old. Each juvenile was assigned an index score based on his/her zip code of residence at time of referral.

\section{Methods of Statistical Analysis}

Given the nested nature of the data (i.e., juveniles within zip codes), hierarchical linear models were used to analyze the data. Since the dependent variables in this study were dichotomous, a hierarchical generalized linear model (HGLM) was used to estimate the impact of individual (Level 1) and community-level (Level 2) data on juvenile court outcomes and subsequent recidivism post age 17 (Raudenbush \& Bryk, 2002). Since the focus of this study is to examine the effect of race and ethnicity net any other effects of juvenile court outcomes unique to that community, Level 1 predictors were presented as group mean-centered. While statewide models (i.e., all counties) were conducted for all dependent variables, separate models for the urban and rural counties were conducted in order to avoid the possible masking of race/ethnicity effects.

\footnotetext{
${ }^{7}$ The measure community disadvantage was used given the focus on economic resources and capital within communities. In fact, measures of racial/ethnic groups did not load on the community disadvantage index. It is important to note that a measure like racial/ethnic heterogeneity tests a very different assumption (i.e., racial threat perspective) than the one proposed here and therefore was not included as a separate predictor of court outcomes.
} 
In order to determine whether the mean diversion, detention, petition, dismissal, out-ofhome placement, and recidivism rate varied across communities (i.e., zip codes), an interceptonly model was first estimated. In instances where the random effects component for the intercept indicated that the rate of diversion, detention, petition, dismissal, out-of-home placement, and recidivism varied significantly across zip codes $(\mathrm{p}<.05)$, the community disadvantage index was included in the models. In cases where the dependent variable did not vary across zip codes, the hierarchical linear model excluded the measure. Thus, a randomcoefficient model including only the individual-level measures was estimated. Only final estimated models are presented here.

\section{FINDINGS}

\section{Descriptives}

Among juveniles referred to the juvenile court in 2000, 67\% were boys and 33\% were girls (see Table 1). Half of juveniles were White while seven percent were Black, 38\% were Hispanic/Latino, and five percent were American Indian. Less than a quarter were public order offenders (23\%) and status offenders (23\%) and more than a quarter were misdemeanor offenders (nine percent were person misdemeanor offenders; seventeen percent were property misdemeanor offenders). Twelve percent were felony offenders (three percent were person felony offenders; nine percent were property felony offenders) and ten percent were drug offenders. Forty-three percent had at least one prior referral and four percent had a dependency petition filed before the instant referral. Nearly three-fourths of juveniles were attending school at the time of referral. Data on jurisdiction type indicates that $66 \%$ of cases were processed in urban counties. A review of the dependent variables shows that $51 \%$ of cases were informally processed or diverted. Of those that were formally processed, 19\% were detained, $71 \%$ had a 
petition filed, 33\% had the petition dismissed, and six percent were removed from the home at disposition. Thirty-three percent of juveniles were rearrested post age 17.

Tables 2 - 7 provide the descriptive information on the relationship between the independent variables and the various dependent variables. ${ }^{8}$ Since the focus of the study is on the influence of race/ethnicity and community disadvantage in juvenile court outcomes and in criminal involvement post age 17 , only the race/ethnicity and community disadvantage descriptive statistics are discussed here.

Preliminary analyses (using $t$-tests for continuous variables and chi-square tests for categorical variables) identified several race/ethnicity differences in informal processing, detention, petition, disposition dismissals, and out-of-home placement outcomes. Analyses show Whites were significantly more likely to be informally processed than other racial/ethnic groups (see Table 2). At the detention stage, a higher proportion of non-Whites (i.e., Blacks, Hispanic/Latinos, and American Indians) were detained than Whites (see Table 3). Bivariate analyses of petition outcomes indicate that a significantly higher proportion of non-Whites than Whites had a petition filed (see Table 4). The only other significant race/ethnicity effect in the petition decision involved Hispanic/Latinos who were significantly more likely to have a petition filed than not filed. At the disposition stage, Black juveniles had a higher proportion of cases dismissed than not dismissed (i.e., adjudicated) (see Table 5). Analyses of the out-of-home placement outcome show that White juveniles were significantly less likely to be removed from the home than other racial/ethnic groups (see Table 6). Also, Hispanic/Latino juveniles were more likely to be removed from the home than placed on community supervision. Bivariate analyses of race/ethnicity and recidivism post age 17 (i.e., arrested as an adult) show that a

\footnotetext{
${ }^{8}$ Bivariate statistics for all analyzed variables can be found in the Appendix B (see Tables 2 - 7).
} 
higher proportion of Black, Hispanic/Latino, and American Indian juveniles were rearrested as adults than Whites (see Table 7).

A review of the significant community disadvantage descriptives revealed that juveniles who were formally processed lived in communities characterized by higher rates of community disadvantage than juveniles who were informally processed. Also, juveniles who were detained lived in communities characterized by higher rates of community disadvantage than juveniles who were not detained.

\section{Racial/ethnic Disparities in Juvenile Court Outcomes}

Tables 8 - 12 present the HGLM estimates for the analyses of juvenile court outcomes. ${ }^{9}$ Since it is possible to mask race/ethnicity effects when examining court processes across multiple jurisdictions, three separate models are presented. These include a statewide model (Model 1), a model with urban counties (Model 2), and model with rural counties (Model 3). This analytical process was particularly important given that jurisdiction type (i.e., urban county) had a significant effect in the statewide models. As such, discussion of the findings will center on the urban and rural county models.

\section{$\underline{\text { Informal Diversion }}$}

Analyses reveal that the main effect of community disadvantage index did not significantly influence the mean rate of informal diversion (see Table 8). Hispanic/Latinos and American Indians were less likely to be informally processed in rural jurisdictions. Specifically, Hispanic/Latinos were .84 times (exp [-.17]) less likely than Whites to be informally processed and American Indians were .61 times (exp [-.49]) less likely than Whites to be informally processed. In urban counties, Blacks were .59 times (exp [-.53]) less likely than Whites to be diverted. Boys were less likely to be informally processed than girls in both urban and rural

\footnotetext{
${ }^{9}$ Models are presented in Appendix B.
} 
jurisdictions. The effects of offense type and seriousness show that person felony and obstruction of justice offenders were less likely than property felony offenders to have their cases informally processed. Person misdemeanor, drug, public order, property misdemeanor, and status offenders were all more likely to be informally processed than property felony offenders in both urban and rural jurisdictions. Not surprisingly, juveniles with a prior record were less likely to be informally processed. Juveniles in urban and rural jurisdictions who were attending school were more likely than juveniles not attending school to be diverted. A dependency petition filed had a negative effect in the diversion outcome. Specifically, juveniles in urban counties who had a prior dependency petition filed were less likely to be informally processed than those who did not have a prior dependency petition filed.

\section{Detention}

Findings in Table 9 show that the main effect of the community disadvantage index significantly influenced the mean rate of detention. In other words, community disadvantage played a significant role in detention decisions, particularly in urban counties. Juveniles who lived in communities characterized by community disadvantage had a higher probability of detention than those juveniles who did not live in such communities.

Analyses show Hispanic/Latinos and American Indians were more likely to be detained than Whites in both urban and rural jurisdictions. In urban counties, Hispanic/Latinos were 1.23 times (exp [.21]) more likely than Whites to detained. In urban counties, American Indians were 2.39 times (exp [.87]) more likely than Whites to detained. Blacks were 1.48 times (exp [.39]) more likely than Whites to be detained in urban jurisdictions. In urban counties, age had a negative effect in the mean rate of detention. Obstruction of justice offenders were more likely to be detained than property felony offenders in both urban and rural jurisdictions. Person felony 
offenders were less likely than property felony offenders to be detained in urban counties.

Status, person misdemeanor, drug, and public order offenders were less likely than property

felony offenders to be detained in rural counties. Juveniles with a prior record were more likely

to be detained in either urban or rural counties. Juveniles attending school in urban counties

were .70 times (exp [-.36]) less likely than juveniles not attending school to be detained.

Juveniles in urban counties who had a prior dependency petition filed were more likely to be detained than juveniles without a history of dependency.

\section{Petition Filed}

Table 10 shows that the main effect of the community disadvantage index significantly influenced the mean rate of petitions filed in urban jurisdictions. Specifically, juveniles who lived in communities characterized by community disadvantage were more likely to have a petition filed than those juveniles who did not live in such communities.

Findings indicate that American Indian juveniles were 1.60 times (exp [.47]) more likely than White juveniles to have a petition filed in rural jurisdictions. The odds of petition filed were no different for Black, Hispanic/Latino and White juveniles in either urban or rural counties. Boys were more likely than girls to have a petition filed and younger juveniles were more likely to have a petition filed. Person felony and obstruction of justice offenders were more likely than property felony offenders to have a petition filed in urban counties. Person misdemeanor, public order, property misdemeanor, status, and drug offenders were all less likely than property felony offenders to have a petition filed. Juveniles with a prior record were more likely to have a petition filed in rural counties. Juveniles in urban counties who were attending school were more likely than juveniles not attending school to have petition filed. Juveniles who had a prior dependency petition filed were less likely than those without a prior dependency petition to have 
a (delinquency) petition filed in urban counties. Not surprisingly, juvenile who had been detained were more likely to have a petition filed in both urban and rural jurisdictions.

\section{Dismissal of Petitions}

Analyses indicate the main effect of the community disadvantage index did not significantly influence the mean rate of dismissal of petitions (see Table 11). Findings also show that Blacks were 1.35 times (exp [.30]) more likely than Whites to have petitions dismissed in urban counties. The odds of petitions dismissal were no different for Hispanic/Latinos, American Indian and White juveniles in either urban or rural counties. Person misdemeanor offenders were more likely than property felony offenders to have the petition dismissed in both urban and rural counties. Similarly, public order, property misdemeanor, and status offenders were more likely than property felony offenders to have the petition dismissed. Juveniles with a prior record were less likely to have petitions dismissed in both urban and rural counties. Juveniles attending school were less likely than juveniles not attending school to have petitions dismissed. Juvenile who were detained were less likely to have petitions dismissed in urban counties.

\section{Out-of-Home Placement}

Analyses of out-of-home placement reveal that the main effect of the community disadvantage index significantly influenced the mean rate of out-of-home placement in urban counties (see Table 12). Juveniles who lived in communities characterized by community disadvantage had a higher probability of out-of-home placement than those juveniles who did not live in such communities.

Findings show that in urban jurisdictions Blacks were 1.90 times (exp [.64]) more likely than Whites to be ordered to an out-of-home placement. The odds of out-of-home placement were no different for Hispanic/Latino, American Indian, and White juveniles in either urban or 
rural jurisdictions. Boys were more likely than girls to be removed from the home in both urban and rural counties. Also, older juveniles were more likely to be dispositioned to an out-of-home placement than younger juveniles. Drug, property misdemeanor, and status offenders were all less likely than property felony offenders to be removed from the home. Juveniles with a prior record were more likely to be removed from the home in both urban and rural counties. Juveniles attending school were .70 times (exp [-.36]) less likely than juveniles not attending school to be ordered to an out-of-home placement in urban jurisdictions. Juveniles in both urban and rural counties who had a dependency petition filed were more likely to be removed from the home at disposition. Lastly, juveniles who were detained were more likely than juveniles not detained to be removed from the home.

The Relationship between Juvenile Court Outcomes and Recidivism Post Age 17

In order to examine the relationship between specific juvenile court actions and reoffending past age 17, separate models containing each of the five court outcomes were specified. Table 13 presents the significant predictors of recidivism including the effect of informal processing. It is important to note that various court actions may have followed the outcomes under examination. Thus, these court outcomes may represent only a snapshot of juveniles' experiences with the juvenile court.

Analyses indicate that the main effect of the community disadvantage index did not significantly influence the mean rate of reoffending post age 17 . Findings show that Hispanic/Latinos and American Indians from both urban and rural counties were more likely than Whites to commit a crime post age 17. Black juveniles from urban counties were also more likely to reoffend than Whites. Boys were more likely to reoffend than girls regardless of jurisdiction type. Public order and status offenders in urban counties were less likely to reoffend 
than property felony offenders. Obstruction of justice offenders from rural counties were more likely than property felony offenders to reoffend. Also, prior record had a positive effect in recidivism post age 17 in both urban and rural counties. Juveniles in urban counties who had a dependency petition filed were more likely to reoffend post age 17.

Including a control for informal diversion revealed that juveniles who were informally processed were less likely to reoffend post age 17 in urban jurisdictions. Models with the detention outcome as a predictor of recidivism reveal that juveniles who were detained were more likely to recidivate post age 17 in both urban and rural counties (see Table 14). Although not presented here, the effects of a petition filed and petition dismissal did not significantly affect recidivism post age 17. However, juveniles who were removed from the home at disposition were more likely to reoffend post age 17 . This effect was significant in both the urban and rural jurisdictions.

\section{DISCUSSION AND IMPLICATIONS FOR RESEARCH, POLICY, AND PRACTICE}

The findings from this study provide clear support for further examinations of race, ethnicity, and community characteristics in juvenile court decision-making processes. Consistent with prior studies, findings reveal that racial and ethnic disparities continue to exist in juvenile courts. Further, not only are these disparities found in front-end court processes (i.e., diversion and dentition) but also prevalent in back-end processes (i.e., out-of- home placement). An important element of these racial and ethnic disparities is how they differ across juvenile court processes. While some racial and ethnic groups experience similar court outcomes, others are uniquely subject to more severe outcomes. For example, Black juveniles were more likely to receive more severe and lenient treatment while American Indians and Hispanic/Latinos were consistently more likely to receive more punitive treatment across certain court outcomes. 
A statewide review of the influence of race and ethnicity in juvenile court outcomes revealed that disparities were found in statewide analyses as well as in certain types of jurisdictions. Although this study included a control for community disadvantage, the juvenile court context (i.e., type of jurisdiction) played a significant role in the outcomes of juveniles. For example, Hispanic/Latinos in the statewide analyses were not treated any differently from their White counterparts in diversion decisions. However, in rural counties, they were less likely to be refereed for informal processing. Also, Black and American Indian juveniles were less likely to be informally processed in the statewide analyses yet Blacks were significantly less likely to be informally processed in urban and not rural jurisdictions. American Indians were less likely to be informally processed in rural jurisdictions yet not in urban counties.

The effects of jurisdiction type in court outcomes revealed that juveniles from urban counties were more likely to be informally processed, detained, and have a petition filed than juveniles in rural counties. In other words, juveniles in urban courts were provided more opportunities for informal processes, including early intervention efforts than juveniles in rural courts. This is especially relevant for American Indians who experienced more harsh treatment in rural than urban courts. In particular, American Indians were less likely to be referred for informal processing, more likely to be detained, and more likely to have a petition filed than Whites. This finding is consistent with prior studies which have found that American Indians receive more severe treatment in court decision-making processes (Poupart, 1995) based on the few non-secure services (e.g., diversion) available for American Indians (Bond-Maupin, Lujan, \& Bortner, 1995).

As noted previously, Black juveniles were treated more severely as well as more leniently in urban courts. Specifically, Black juveniles were more likely to be formally processed, more 
likely to be detained, more likely to have a petition dismissed by a judge, and more likely to be removed from the home at disposition. This finding is consistent with previous studies which document how court officials correct the over-representation of Black youth. Some studies have found that racial disparities/biases that surface early on in juvenile justice system processing may be “corrected” at subsequent stages. Leiber and Mack (2003) found that Black juveniles received dispositions involving both harshness and leniency. Dannefer and Schutt (1982) proposed juvenile court officials may be compensating for pro-active arrest policies which disproportionately impact certain offenders. Most recently, Rodriguez (2007) found that the less severe treatment received by Blacks at detention may be due to the "self correct" process carried out by court officials in response to the high arrest rates among Black juveniles. The fact that Blacks were more likely to have petitions dismissed and be removed from the home represents the dynamic nature of court processes and the mixed effect of race across court outcomes.

The effect of Hispanic/Latinos in court outcomes was most felt in the diversion and detention decisions. In rural courts, Hispanic/Latinos were less likely to be informally processed and in both urban and rural courts, they were more likely to be detained than White juveniles. These findings are consistent with prior studies that report more severe treatment among Hispanic/Latinos in court outcomes (Brown \& Warner, 1992; Demuth, 2002; 2003; Portillos, 2002). The disparate treatment experienced by this population of juveniles may be a product of a broader political climate surrounding illegal immigration and border security (Rodriguez, 2007). Hispanic/Latinos may be particularly vulnerable of formal processing and detention given the lack of alternative resources in rural counties and/or perceived threat to the larger community. As expected, the effect of detention was significant in subsequent court outcomes. This finding is consistent with prior studies which document the negative effect of detention in 
subsequent stages of processing (Bishop \& Frazier, 1988, 1992; Bortner \& Reed, 1985; Feld, 1993). Specifically, juveniles who were detained were more likely to have a petition filed (in both jurisdiction types), less likely to have petitions dismissed in urban counties, and more likely to be removed from the home at disposition in both urban and rural courts. These findings highlight the need for multistage studies that incorporate how early court processing stages impact later court decisions. That is, if disparities occurring at early decision points are not examined, analyses of later decision-making processes will likely underestimate the influence of race and ethnicity (Bishop \& Frazier, 1996; Bortner \& Reed, 1985). The dangers of detention have been well-documented. This study, like prior work, shows the critical role detention plays in court outcomes and how even short-term incarceration of juveniles can lead to more severe treatment and indirectly produces racial/ethnic disparities in the justice system.

One of the important dimensions of this study was the inclusion of the control variable community disadvantage. This measure was different from the majority of previous studies which include such a measure in their analyses (Armstrong \& Rodriguez, 2005; Feld, 1991; Frazier \& Lee, 1992; Sampson \& Laub, 1993; Secret \& Johnson, 1997; Wu, Cernkovich, \& Dunn, 1997). In this study, this measure was captured at the community-level rather than as an overall county or city measure. Findings from this study indicate that community disadvantage was a significant factor in detention, petition, and out-of-home placement decisions in urban courts. Juveniles who lived in communities characterized by community disadvantage were more likely to receive more severe treatment by the court. These findings call attention to the importance of examining intra-city community factors in studies of juvenile court decisionmaking processes. It is important to note that community disadvantage was not a significant predictor in the mean rates of court outcomes in rural jurisdictions. This may be due to the 
different type of communities found in urban and rural jurisdictions. Another possibility is the homogeneity that may exist across rural jurisdictions. In other words, the dependent variables varied across the rural zip codes, yet the communities were far more similar in community disadvantage but varied along an unmeasured dimension. This may explain why the dependent variables often varied across rural communities but the community disadvantage measure failed to reach any meaningful level of significance. One important community-level measure that was not included in the index was racial/ethnic heterogeneity. It was not part of the index given its low loading on the community disadvantage index. The inclusion of this measure in future studies may provide insight into the relationship between community characteristic and court processes in rural counties.

One powerful element of the study was the ability to track juvenile offenders past their 17 birthday and assess levels of recidivism given varying court outcomes. Results indicate that racial and ethnic minorities were more likely to reoffend past their $17^{\text {th }}$ birthday than their White counterparts. This is true for Hispanic/Latino, Black, and American Indian juveniles. Blacks were more likely to reoffend when processed in urban jurisdictions while Hispanic/Latinos and American Indians were more likely to reoffend when processed in either urban or rural jurisdictions. Also, offenders in urban jurisdictions who were informally processed were less likely to reoffend as adults. A review of analysis for juvenile who were formally processed show that juveniles who were detained and removed from the home at disposition were also more likely to appear in the adult criminal justice system. These findings provide support for how more serious juvenile court outcomes can lead to long-term negative consequences.

In the end, what insight does this study provide for juvenile justice practice and policy? 
Any effort aimed at addressing racial/ethnic biases must consider the context of the juvenile court as well as the community characteristics of the juveniles who come to the attention of the juvenile court. As proposed by previous research and demonstrated in this study, racial and ethnic disparities can be masked when statewide reviews are conducted. In other words, attempts at eradicating disparities must first focus on identifying the nature of the disparities at the local level. This will require comprehensive reviews of racial/ethnic disparities across multiple decision points and during an on-going basis. Further, attention must also be given to the community characteristics of juveniles as they are significant predictors of juvenile court outcomes. This includes focusing attention on the resources (or lack of) that are available for juveniles in their respective communities. Researchers have suggested that changing dynamics of society have the potential to create different forms of disparities (Bridges \& Crutchfield, 1988). If juveniles from disorganized communities are at a higher risk for more severe treatment (Rodriguez, 2007; Bortner, 1982; Drass \& Spencer, 1987), efforts must be made to address how the courts classify such cases. This includes directing resources towards juveniles without removing them from home. Since public safety often trumps the needs of children, juvenile justice systems across jurisdictions must be active participants at national, state, and local discussions about crime prevention and interventions.

Findings from this study indicate that racial/ethnic biases exist at initial, front-end processes as well as back-end processes. This is particularly important as efforts aimed at reducing disparities at detention, like JDAI, cannot alone reduce the disparities that take place post detention processes. Consistent with prior studies, the effects of detention are felt long past that decision. Since all racial/ethnic juveniles were more likely to be detained than their White counterparts, it is critical to better understand why each of these racial/ethnic groups were 
detained. Doing so will require a far better understanding of the social factors that may be specifically influential in the lives of certain juveniles. To assume that the biases are a product of similar factors will likely not address the biases associated with detention. For example, we need far better insight on whether the reasons Black juveniles are detained and removed from the home are the same for other racial/ethnic groups. Also, are the reasons why minority juveniles less likely to be informally processed the same for all juveniles? Why are certain juveniles afforded informal processes more so than others? Critical to these questions is context. These processes are context specific and need to be regarded as such.

The influence of dependency in court outcomes is particularly important. Study findings indicate that juveniles who had a prior dependency petition filed were treated more severely by the court. Juveniles who may be at risk of abuse and/or neglect may be particularly vulnerable to detention and out-of-home placements. Juvenile courts need to collaborate with social service agencies to identity those juveniles who may be at risk of falling into juvenile court jurisdiction. Also, a closer review of the relationship between race/ethnicity and dependency petitions may shed light on the extent to which disparities may be tied to higher levels of abuse or neglect among certain racial and ethnic groups.

Findings indicate there is a relationship between juvenile court outcomes and reoffending as adults. Although these findings should be interpreted with caution as there may be several important predictors of offending that were not captured in this study, the relationship between court outcomes and reoffending is strong. Diversion should continue to be an option for many juveniles who enter the juvenile court system. In fact, juvenile court officials should use these findings as support for why prevention and intervention programs are critical to the court. Also, court officials may want to work more closely with the adult criminal justice system in an effort 
to try to reduce the population of juveniles that enter the adult criminal justice system. While these formal or informal relationships tend to focus on addressing the more violent offenders in the system (i.e., transfer and remanded youth), collaborations aimed at reducing adult offending among all juveniles may be extremely valuable.

It is important to note various limitations of this study. First, the study did not examine the effect of race/ethnicity in specific jurisdictions in Arizona. While analysis of jurisdiction types (i.e., urban and rural) were conducted, the findings reported here cannot be generalized to individual counties in Arizona. Second, the data used in this study come from official court records and do not include qualitative data from either court officials or juveniles. While qualitative data from officials, juveniles, and case files would have certainly supplemented the quantitative data used in this study, time constraints restricted the collection of such data. Third, the study was unable to control for psychological dimensions and family situational factors (e.g., parents' income) which are both relevant in juvenile court decision-making processes.

In sum, research of juvenile court decision-making processes should expand theoretical and empirical focus to racial and ethnic groups that continue to receive minimal attention in studies of racial/ethnic disparities. Results of this study have expanded the knowledge that exists in criminal justice literature with respect to racial and ethnic disparities in juvenile court processes. Also, researchers should attempt to include community dynamics (macro and micro) into studies of juvenile court outcomes for a more comprehensive review of disparities in the juvenile justice system. Lastly, efforts to identify the relationship between specific juvenile court actions and reoffending should not only focus on offending that takes place during adolescence but also during adulthood. 


\section{Appendix A}

\section{References}

Albonetti, C. (1991). Integration of theories to explain judicial discretion. Social Problems, 38, 247-266.

Armstrong, G. \& Rodriguez, N. (2005). Effects of individual and contextual characteristics on preadjudication detention of juvenile delinquents. Justice Quarterly, 22(4), 521- 539.

Bachman, R., Alvarez, A., \& Perkins, C. (1996). Discriminatory imposition of the law: Does it affect sentencing outcomes for American Indians? In M.O. Nielsen \& R.A. Silverman, (Eds.), Native Americans, crime, and justice. New York, N.Y.: Westview Press.

Berk, R. (1983). An introduction to sample selection bias in sociological data. American Sociological Review, 48, 386-398.

Bishop, D.M., \& Frazier, C.E. (1988). The influence of race in juvenile justice processing. Journal of Research in Crime and Delinquency, 25(3), 242-263.

Bishop, D. M. \& Frazier, C.E. (1996). Race effects in juvenile justice decision-making: Findings of a statewide analysis. Journal of Criminal Law and Criminology, 86, 392413.

Bortner, M.A. (1982). Inside a juvenile court: The tarnished ideal of individualized justice.New York, N.Y.: Columbia University Press.

Bortner, M.A. \& Reed, W.L. (1985). Preeminence of process: An example of refocused justice research. Social Science Quarterly, 66, 413-425.

Bridges, G. S. \& Crutchfield, R.D. (1988). Law, social standing, and racial disparities in imprisonment. Social Forces, 66, 601-616.

Bridges, G. S., Conley, D., Beretta, G. R., Engen, R.. L., Price-Spratlen, T., Rankin, M., et al., (1993). Racial disproportionality in the juvenile justice system: Final report. Olympia, WA: Washington Department of Social and Health Services.

Bridges, G. S. \& Steen, S. (1998). Racial disparities in official assessments of juvenile offenders: Attributional stereotypes as mediating mechanisms. American Sociological Review, 63, $554-570$.

Brown, C.M \& Warner, B.D. (1992). Immigrants, urban politics, and policing in 1900. American Sociological Review, 57, 293-305. 
Bynum, T.S. \& Paternoster, R. (1984). Discrimination revisited: An exploration of frontstage and backstage criminal justice decision making. Sociology and Social Research, 69, 90-108.

Crawford, C., Chiricos, T., \& Kleck, G. (1998). Race, racial threat, and sentencing of habitual offenders. Criminology, 36, 481-511.

DeJong, C. \& Jackson, K. (1998). Putting race into context: Race, juvenile justice processing, and urbanization. Justice Quarterly, 15, 487-504.

Dannefer, D. \& Schutt, R.K. (1982). Race and juvenile justice processing in court and police agencies. American Journal of Sociology, 87, 1113-1132.

Demuth, S. (2002). The effect of citizenship status on sentencing outcomes in drug cases. Federal Sentencing Reporter, 14, 271-275.

Demuth, S. (2003). Racial and ethnic differences in pretrial release decisions and outcomes: A comparison of Hispanic, Black, and White felony arrestees. Criminology, 41, 873-908.

Drass, K.A. \&. Spencer, W. J. (1987).Accounting for pre-sentencing recommendations: Typologies and probation officers' theory of office. Social Problems, 34, 277-293.

Elliott, D.S. (1994). Serious violent offenders: Onset, developmental course, and termination - The American Society of Criminology 1993 presidential address. Criminology, 32, 1-21.

Emerson, R. M. (1969). Judging delinquents: Context and process in juvenile court. Chicago, Illinois: Aldine Publishing Company.

Engen, R. L., Steen, S., \& Bridges, G.S. (2002). Racial disparities in the punishment of youth: A theoretical and empirical assessment of the literature. Social Problems, 49,194-220.

Feld, B. C. (1991). Justice by geography: Urban, suburban, and rural variations in juvenile justice administration. The Journal of Criminal Law \& Criminology, 82, 156-210.

Frazier, C. E. \& Bishop, D.M. (1985). Pretrial detention of juveniles and its impact on case dispositions. Journal of Criminal Law and Criminology, 76, 1132- 1152.

Frazier, C. E., \& D.M. Bishop. (1995). Reflections on race effects in juvenile justice in Minorities in juvenile justice, K. Kempf-Leonard, C. Pope, and W. Feyerherm (eds) (pp. 16-26). Thousand Oaks, CA: Sage. 
Frazier, C. E., Bishop, D. M., \& Henretta, J. (1992). The social context of race differentials in juvenile justice dispositions. Sociological Quarterly, 33, 447-458.

Frazier, C.E. \& Cochran, J. (1986). Detention of juveniles: Its effects on subsequent juvenile court processing decisions. Youth \& Society, 17, 286-385.

Frazier, C. E. \& Lee, S.R. (1992). Reducing juvenile detention rates or expanding the official control nets: An evaluation of a legislative reform effort. Crime \& Delinquency, 38, 204-218.

Gaarder, E., Rodriguez, N. \& M. S. Zatz. (2004). Crier, liars, and manipulators: Probation officers' views of girls. Justice Quarterly 21:547-578.

Gottfredson, M.R. \& Hirschi, T. (1990). A general theory of crime. Stanford, CA: Stanford University Press.

Guevara, L., D. Herz, \& C. Spohn. (2006). Gender and juvenile justice decision making: What role does race play? Feminist Criminology, 1, 258-282.

Hawkins, D., Laub, J., \& Lauritsen, J. (1998). Race, Ethnicity, and Serious Juvenile Offending. In R. Loeber and D. Farrington (eds)., Serious \& Violent Juvenile Offenders: Risk Factors and Successful Interventions (pp. 30-46). Thousand Oaks, CA: Sage Publications.

Hindelang, M. (1978). Race and involvement in common law personal crimes. American Sociological Review, 43, 93-109.

Land, K.C. (2000). Influence of neighborhood, peer, and family context: Trajectories of delinquent/criminal offending across the life course, final report. Washington, DC: U.S. Department of Justice, National Institute of Justice.

Leiber, M. J. (1994). Comparison of juvenile court outcomes for Native Americans, African Americans, and Whites. Justice Quarterly, 11, 257-279.

Leiber, M. J. (1995). Toward clarification of the concept of "minority" status and decision-making in juvenile court proceedings. Journal of Crime and Justice, 18,79108.

Leiber, M.J. \& K. C. Fox. (2005). Race and the Impact of Detention on Juvenile Justice Decision Making. Crime \& Delinquency, 51, 470-497.

Leiber, M.J. \& Jamieson, K.M. (1995). Race and decision making within juvenile justice: The importance of context. Journal of Quantitative Criminology, 11, 363-388. 
Leiber, M.J. \& K.Y. Mack. 2003. The individual and joint effects of race, gender, and family status on juvenile justice decision-making. Journal of Research in Crime and Delinquency, 40, 34-70.

Leiber, M. \& Stairs, J.M. (1999). Race, context, and the use of intake diversion. Journal of Research in Crime and Delinquency, 36, 56-86.

Lynch, J.P. (2002). Trends in juvenile violent offending: An analysis of victim survey data. Washington, DC: Department of Justice, Office of Juvenile Justice and Delinquency Prevention. http://www.ncjrs.gov/html/ojjdp/jjbul2002_10_1/contents.html

McCarthy, B.R. \& B.L Smith. (1986). The conceptualization of discrimination in the juvenile justice process: The impact of administrative factors and screening decisions on juvenile court dispositions. Criminology, 24, 41-64.

Mata, A.G. \& Herrerías, C. (2002). Latinos and Latinos: Immigrant bashing the nativist political movements. In C. Richey Mann \& M. S. Zatz (Eds.), Images of color, images of crime. Los Angeles, Ca.: Roxbury.

Maupin, J., R. \& Bond-Maupin, L.J. (1999). Detention decision-making in a predominantly Hispanic region: Rural and non-rural differences. Juvenile and Family Court Journal, 50, 11-23.

Miller. J. (1996). An examination of disposition decision making for delinquent girls. In M D. Schwartz \& D. Milovanovic (Eds.), Race, gender, and class in criminology: The intersection. New York: Garland Publishing.

Minor, K., Hartmann, D., \& Terry, S. (1997). Predictors of juvenile court actions and recidivism. Crime \& Delinquency, 43, 3, 328-344

O’Neill, B.F. (2002). Influences on detention decisions in the juvenile justice system. Juvenile and Family Court Journal, 53(1), 47-58.

Peterson, R.D. \& Hagan, J. (1984). Changing conceptions of race: Towards an account of anomalous findings of sentencing research. American Sociological Review, 49, 5670 .

Pope, C. \& W. Feyerherm. (1990). Minority status and juvenile justice processing: An assessment of the research literature (Parts I and II). Criminal Justice Abstracts, 22:327-336 (part I), 22:527-542 (part II).

Pope, C.E., Lovell, R., \& Hsia, H.M. (2002). Disproportionate minority confinement: A review of the research literature from 1989 through 2001. Washington, D.C.: U.S. Department of Justice, Office of Juvenile Justice and Delinquency Prevention. 
Portes, A. (1990). From south of the border: Hispanic minorities in the United States. In V. Yans-McLaughlin (Ed.), Immigration reconsidered: History, sociology, and politics. New York: Oxford University Press.

Portillos, E.L. (2002). Latinos and Latinas: Latinos, Gangs, and Drugs. In C. Richey Mann \& M. S. Zatz (Eds.), Images of color, images of crime. Los Angeles, Ca.: Roxbury.

Raudenbush, S.W. \& Bryk, A.S. (2002). Hierarchical linear models: Applications and data analysis methods. ( $2^{\text {nd }}$ ed.). Thousand Oaks, CA: Sage Publications.

Rodriguez, N. (2007). Juvenile court context and detention decisions: Reconsidering the role of race, ethnicity, and community characteristics in juvenile court processes. Justice Quarterly 24:629-656.

Sampson, R.J. \& Laub, J.H. (1993). Structural variations in juvenile court processing: Inequality, the underclass, and social control. Law \& Society Review, 27, 285-311.

Sarri, R. (1983). Gender issues in juvenile justice. Crime \& Delinquency, 381-397.

Schutt, R.K. \& Dannefer, D. (1988). Detention decisions in juvenile cases: JINS, JDs, and gender. Law and Society Review, 22, 509-520.

Secret, P.E. \& Johnson, J.B. (1997). The effect of race on juvenile, justice decision making in Nebraska: Detention, adjudication, and disposition, 1998-1993. Justice Quarterly, 14, 445-478.

Smith, D.A. \& Paternoster, R. (1990). Formal processing and future delinquency: Deviance amplification as selection artifact. Law \& Society Review, 24, 5, 1109-1131.

Snyder, H.N. \& M. Sickmund. (1999). Minorities in the Juvenile Justice System. Online: http://www.ncjrs.gov/pdffiles1/ojjdp/179007.pdf

Steffensmeier, D. \& Demuth, S. (2000). Ethnicity and sentencing outcomes in US federal courts: Who is punished more harshly? American Sociological Review, 65, 705-729.

Steffensmeier, D., Ulmer, J., \& Kramer, J. (1998). Interaction of race, gender, and age in criminal sentencing: The punishment cost of being young, Black, and male. Criminology, 36, 763-797.

Wooldredge, J. (1988). Differentiating the effects of juvenile court sentences on eliminating recidivism. Journal of Research in Crime and Delinquency, 25, 264-300.

Wordes, M., Bynum, T. S., \& Corley, C.J. (1994). Locking up youth: The impact of race on detention decision. Journal of Research in Crime and Delinquency, 31,149-165. 
Wu, B. (1997). The effect of race and juvenile justice processing. Juvenile \& Family Court Judges, 48, 43-51.

Wu, B., Cernkovich, S., \& Dunn, C.S. (1997). Assessing the effects of race and class on juvenile justice processing in Ohio. Journal of Criminal Justice, 25, 265-277.

Wu, B. \& Fuentes, A. (1998). The entangled effects of race and urban poverty. Juvenile \& Family Court Journal, 49, 41-53.

Young, T.J. (1990). Native American crime and criminal justice require criminologists' attention. Journal of Criminal Justice Education, 1, 111-116.

Zatz, M.S., Lujan, C.C., \& Snyder-Joy, Z.K. (1991). American Indians and criminal justice: Some conceptual and methodological considerations. In M. J. Lynch \& E. B. Patterson (Eds.), Race and criminal justice. New York: Harrow and Heston. 


\section{Appendix B.}

Table 1. Frequencies of Independent and Dependent Variables

\section{Independent Variables}

Sex

Boys

Girls

Race/ethnicity

White

Black

Hispanic/Latino

American Indian

Age

School Status

Attending

Not Attending

Referral

Person-Felony

Person-Misdemeanor

Property-Felony

Property-Misdemeanor

Drugs

Public Order

Status

Obstruction of Justice

Dependency Petition Filed

Yes

No

Prior Referrals

Yes

No

Urban County

Yes

No

Disadvantage Index

Dependent Variables

Informal Processed

Yes

No

Detention $^{\mathrm{a}}$

Yes

No

Petition Filed ${ }^{\mathrm{a}}$

Yes

No

Petition Dismissed

Yes

No

Out-of-Home Placement ${ }^{\mathrm{c}}$

Yes

No

Recidivism Post Age 17

Yes

No

$\mathrm{N}=18,927 ;{ }^{\mathrm{a}} \mathrm{N}=9,312 ;{ }^{\mathrm{b}} \mathrm{N}=6,590 ;{ }^{\mathrm{c}} \mathrm{N}=4,232$ $\underline{\%}$

$66.9 \%$

$33.1 \%$

$50.3 \%$

$6.6 \%$

$37.9 \%$

$5.3 \%$

Mean $=15.16 ;(S D)=1.99$

$73.3 \%$

$26.7 \%$

$3.1 \%$

$9.2 \%$

$8.5 \%$

$16.6 \%$

$9.5 \%$

$23.2 \%$

$23.3 \%$

$6.5 \%$

$3.6 \%$

$96.4 \%$

$42.6 \%$

$57.4 \%$

$65.8 \%$

$34.2 \%$

Mean $=0.11 ;(S D)=.99$
$51 \%$

$49 \%$

$19 \%$

$81 \%$

$71 \%$

$29 \%$

$33 \%$

$67 \%$

$6 \%$

$94 \%$

$33 \%$

$67 \%$ 
Table 2. Bivariate Statistics of Formally and Informally Processed Cases

Individual-Level

Sex*

Boys

Girls

Race/ethnicity

White*

Black*

Hispanic/Latino

American Indian

Age*

School Status*

Attending

Not Attending

Referral

Person-Felony*

Person-Misdemeanor *

Property-Felony*

Property-Misdemeanor*

Drugs*

Public Order*

Status*

Obstruction of Justice*

Dependency Petition Filed*

Yes

No

Prior Referrals*

Yes

No

Urban County*

Yes

No

Community-Level

Disadvantage Index*
$46.0 \%$

$60.4 \%$

$52.8 \%$

$39.7 \%$

$50.2 \%$

$50.1 \%$

Mean $=15.43 ;(S D)=1.98$

$52.2 \%$

$47.0 \%$

$7.9 \%$

$45.4 \%$

$17.3 \%$

$74.9 \%$

$33.7 \%$

$53.4 \%$

$71.0 \%$

$4.3 \%$

$51.7 \%$

$26.4 \%$

$65.4 \%$

$31.1 \%$

$53.4 \%$

$49.5 \%$

Mean $=-.02 ;(S D)=.98$

$51 \%$
$54.0 \%$

$39.6 \%$

$47.2 \%$

$60.3 \%$

$49.8 \%$

$49.9 \%$

Mean $=14.91 ;(S D)=1.97$

$47.8 \%$

$53.0 \%$

$92.1 \%$

$54.6 \%$

$82.7 \%$

$25.1 \%$

$66.3 \%$

$46.6 \%$

$29.0 \%$

$95.7 \%$

$48.3 \%$

$73.6 \%$

$34.6 \%$

$68.9 \%$

$46.6 \%$

$50.5 \%$

Mean $=.04 ;(S D)=1.00$

$\mathrm{N}=18,927$

$49 \%$

\footnotetext{
$* t$ test or Chi-square significant at $\mathrm{p}<.05$.
} 
Table 3. Bivariate Statistics of Juvenile Detention Outcome

Individual-Level

Sex*

Boys

$19.4 \%$

$80.6 \%$

Girls

$17.5 \%$

$82.5 \%$

Race/ethnicity

White*

$15.8 \%$

$84.2 \%$

Black*

$26.1 \%$

$73.9 \%$

Hispanic/Latino*

$20.8 \%$

$79.2 \%$

American Indian*

$23.2 \%$

$76.8 \%$

Age

Mean = 15.43; $(\mathrm{SD})=2.05$

Mean $=15.45 ;(S D)=1.64$

School Status

Attending

$18.8 \%$

$81.2 \%$

Not Attending

$19.2 \%$

$80.8 \%$

Referral

Person-Felony*

$13.3 \%$

$86.7 \%$

Person-Misdemeanor*

$15.9 \%$

$84.1 \%$

Property-Felony*

$16.3 \%$

$83.7 \%$

Property-Misdemeanor

$19.6 \%$

$80.4 \%$

Drugs*

$14.3 \%$

$85.7 \%$

Public Order*

$12.1 \%$

$87.9 \%$

Status *

$13.8 \%$

$86.3 \%$

Obstruction of Justice*

$48.8 \%$

$51.2 \%$

Dependency Petition Filed*

Yes

$35.2 \%$

$64.8 \%$

No

$18.0 \%$

$82.0 \%$

Prior Referrals*

Yes

$25.7 \%$

$74.3 \%$

No

$8.8 \%$

$91.2 \%$

Urban County

Yes

$21.8 \%$

$78.2 \%$

No

$12.9 \%$

$87.1 \%$

Community-Level

Disadvantage Index*

Mean=.12; $(\mathrm{SD})=1.02$

Mean=.02; $(\mathrm{SD})=1.00$

$\mathrm{N}=9,312$

$19 \%$

$81 \%$

$* t$ test or Chi-square significant at $\mathrm{p}<.05$. 
Table 4. Bivariate Statistics of Juvenile Petitions Filed

Individual-Level

Sex*

Boys

Girls

Race/ethnicity

White*

Black

Hispanic/Latino*

American Indian

Age*

School Status*

Attending

Not Attending

Person-Felony

Person-Misdemeanor*

Property-Felony*

Property-Misdemeanor

Drugs

Public Order*

Status*

Obstruction of Justice*

Dependency Petition Filed

Yes

No

Prior Referrals*

Yes

No

Urban County*

Yes

No

Community-Level

Disadvantage Index
Referral

$72.6 \%$

$65.7 \%$

$69.3 \%$

$72.1 \%$

$72.1 \%$

$73.0 \%$

Mean =15.56; $(\mathrm{SD})=2.29$

$72.3 \%$

$67.0 \%$

$71.9 \%$

$64.4 \%$

$78.7 \%$

$69.1 \%$

$70.2 \%$

$59.9 \%$

$63.0 \%$

$95.5 \%$

$71.1 \%$

$70.8 \%$

$75.0 \%$

$64.6 \%$

$74.9 \%$

$62.2 \%$

Mean=.04; $(\mathrm{SD})=1.00$

$71 \%$

$\mathrm{N}=9,312$

$* t$ test or Chi-square significant at $\mathrm{p}<.05$.
$27.4 \%$

$34.3 \%$

$30.7 \%$

$27.9 \%$

$27.9 \%$

$27.0 \%$

Mean $=15.38 ;(S D)=1.82$

$27.7 \%$

$33.0 \%$

$28.1 \%$

$35.6 \%$

$21.3 \%$

$30.9 \%$

$29.8 \%$

$40.1 \%$

$37.0 \%$

$4.5 \%$

$28.9 \%$

$29.2 \%$

$25.0 \%$

$35.4 \%$

$25.1 \%$

$37.8 \%$

Mean=.03; $(\mathrm{SD})=.99$ 
Table 5. Bivariate Statistics of Judicially Dismissed Petitions

Individual-Level

Sex*

Boys

$31.6 \%$

$68.4 \%$

Girls

$38.3 \%$

$61.7 \%$

Race/ethnicity

White

$32.6 \%$

$67.4 \%$

Black*

$38.6 \%$

$61.4 \%$

Hispanic/Latino

$32.7 \%$

$67.3 \%$

American Indian

$35.1 \%$

$64.9 \%$

Age*

School Status*

Attending

Mean =15.50; $(\mathrm{SD})=1.63$

Mean $=15.11 ;(S D)=2.14$

Not Attending

$30.1 \%$

$69.9 \%$

$41.6 \%$

$58.4 \%$

Referral

Person-Felony*

$25.6 \%$

$74.4 \%$

Person-Misdemeanor*

$37.2 \%$

$62.8 \%$

Property-Felony*

$20.6 \%$

$79.4 \%$

Property-Misdemeanor

$29.9 \%$

$70.1 \%$

Drugs*

$18.4 \%$

$81.6 \%$

Public Order*

$47.5 \%$

$52.5 \%$

Status*

$61.8 \%$

$38.2 \%$

Obstruction of Justice*

$22.1 \%$

$77.9 \%$

Dependency Petition Filed

Yes

$33.4 \%$

$66.6 \%$

No

$33.2 \%$

$66.8 \%$

Prior Referrals*

Yes

$28.5 \%$

$71.5 \%$

No

$41.3 \%$

$58.7 \%$

Urban County*

Yes

$34.4 \%$

$65.6 \%$

No

$30.3 \%$

$69.7 \%$

Community-Level

Disadvantage Index

Mean=.07; $(\mathrm{SD})=1.06$

Mean=.03; $(\mathrm{SD})=.98$

$\mathrm{N}=6,590$

$33 \%$

$67 \%$

$* t$ test or Chi-square significant at $\mathrm{p}<.05$. 
Table 6. Bivariate Statistics of Out-of-Home Placement

Individual-Level

Sex*

Boys

Girls

Race/ethnicity

White*

Black

Hispanic/Latino*

American Indian

Age*

School Status*

Attending

Not Attending

Referral

Person-Felony

Person-Misdemeanor

Property-Felony

Property-Misdemeanor*

Drugs

Public Order

Status*

Obstruction of Justice*

Dependency Petition Filed*

Yes

No

Prior Referrals*

Yes

No

Urban County

Yes

No

Community-Level

Disadvantage Index
$6.4 \%$

$2.8 \%$

$4.1 \%$

$7.9 \%$

$6.7 \%$

$6.3 \%$

Mean =15.43; $(\mathrm{SD})=1.63$

$4.3 \%$

$9.8 \%$

$7.6 \%$

$4.4 \%$

$5.0 \%$

$2.5 \%$

$4.2 \%$

$5.5 \%$

$0.4 \%$

$9.9 \%$

$17.0 \%$

$4.9 \%$

$7.8 \%$

$0.9 \%$

$5.7 \%$

$5.2 \%$

Mean=.09; $(\mathrm{SD})=.86$

$6 \%$

$\mathrm{N}=4,232$

$* t$ test or Chi-square significant at $\mathrm{p}<.05$.
$93.6 \%$

$97.2 \%$

$95.9 \%$

$92.1 \%$

$93.3 \%$

$93.7 \%$

Mean $=16.12 ;(S D)=1.26$

$95.7 \%$

$90.2 \%$

$92.4 \%$

$95.6 \%$

$95.0 \%$

$97.5 \%$

$95.8 \%$

$94.5 \%$

$99.6 \%$

$90.1 \%$

$83.0 \%$

$95.1 \%$

$92.2 \%$

$99.1 \%$

$94.3 \%$

$94.8 \%$

Mean=.03; $(\mathrm{SD})=.99$

$94 \%$ 
Table 7. Bivariate Statistics of Recidivism Post Age 17

Individual-Level

Sex*

Boys

Girls

Race/ethnicity

White*

Black*

Hispanic/Latino*

American Indian*

Age*

School Status

Attending

Not Attending

Referral

Person-Felony*

Person-Misdemeanor

Property-Felony*

Property-Misdemeanor*

Drugs*

Public Order*

Status *

Obstruction of Justice*

Dependency Petition Filed*

Yes

No

Prior Referrals*

Yes

No

Urban County*

Yes

No

Informal Diversion*

Yes

No

Detention*

Yes

No

Community-Level

Disadvantage Index
$62.5 \%$

$80.5 \%$

$70.0 \%$

$63.2 \%$

$65.0 \%$

$65.3 \%$

Mean =15.70; (SD) $=1.57$

$67.2 \%$

$67.5 \%$

$65.5 \%$

$71.1 \%$

$65.5 \%$

$62.9 \%$

$65.8 \%$

$70.7 \%$

$77.0 \%$

$54.9 \%$

$60.2 \%$

$67.7 \%$

$59.2 \%$

$79.2 \%$

$63.5 \%$

$75.1 \%$

$21.2 \%$

$32.7 \%$

$47.0 \%$

$29.4 \%$

Mean=.02; $(\mathrm{SD})=1.00$

$33 \%$

Note: Bivariate statistics excludes informally processed juveniles.

$* t$ test or Chi-square significant at $\mathrm{p}<.05$.
$37.5 \%$

$19.5 \%$

$30.0 \%$

$36.8 \%$

$35.0 \%$

$34.7 \%$

Mean =14.98; $(\mathrm{SD})=2.09$

$32.8 \%$

$32.5 \%$

$34.5 \%$

$28.9 \%$

$34.5 \%$

$37.1 \%$

$34.2 \%$

$29.3 \%$

$23.0 \%$

$45.1 \%$

$39.8 \%$

$32.3 \%$

$40.8 \%$

$20.8 \%$

$36.5 \%$

$24.9 \%$

$78.8 \%$

$67.3 \%$

$53.0 \%$

$70.6 \%$

Mean= $-.01 ;(S D)=.95$

$67 \%$ 
Table 8. HGLM Estimates of Informally Processed Case Outcome

\begin{tabular}{|c|c|c|c|}
\hline & $\begin{array}{l}\text { Model } 1^{b} \\
\text { Statewide }\end{array}$ & $\begin{array}{c}\text { Model } 2^{\mathrm{C}} \\
\text { Urban } \\
\text { Counties }\end{array}$ & $\begin{array}{c}\text { Model 3 } \\
\text { Rural } \\
\text { Counties }\end{array}$ \\
\hline Intercept $^{\mathrm{a}}$ & $\begin{array}{c}-0.053 \\
(0.046)\end{array}$ & $\begin{array}{c}-0.198^{* * *} \\
(0.049)\end{array}$ & $\begin{array}{c}-0.067 \\
(0.074)\end{array}$ \\
\hline \multicolumn{4}{|l|}{ Individual-Level Indicator } \\
\hline Sex & $\begin{array}{c}-0.191 * * * \\
(0.038)\end{array}$ & $\begin{array}{c}-0.156^{* *} \\
(0.048)\end{array}$ & $\begin{array}{c}-0.242^{* * *} \\
(0.064)\end{array}$ \\
\hline Black & $\begin{array}{c}-0.480^{* * *} \\
(0.079)\end{array}$ & $\begin{array}{c}-0.530 * * * \\
(0.090)\end{array}$ & $\begin{array}{c}-0.280 \\
(0.188)\end{array}$ \\
\hline Hispanic/Latino & $\begin{array}{c}-0.063 \\
(0.046)\end{array}$ & $\begin{array}{c}-0.011 \\
(0.056)\end{array}$ & $\begin{array}{c}-0.170 * \\
(0.081)\end{array}$ \\
\hline American Indian & $\begin{array}{c}-0.309 * * \\
(0.103)\end{array}$ & $\begin{array}{c}-0.130 \\
(0.155)\end{array}$ & $\begin{array}{c}-0.485^{* *} \\
(0.140)\end{array}$ \\
\hline Age & $\begin{array}{c}0.006 \\
(0.010)\end{array}$ & $\begin{array}{c}0.005 \\
(0.013)\end{array}$ & $\begin{array}{c}0.013 \\
(0.015)\end{array}$ \\
\hline School Status & $\begin{array}{c}0.513^{* * *} \\
(0.043)\end{array}$ & $\begin{array}{c}0.522 * * * \\
(0.055)\end{array}$ & $\begin{array}{c}0.465^{* * *} \\
(0.071)\end{array}$ \\
\hline Person-Misdemeanor & $\begin{array}{c}1.455^{* * *} \\
(0.088)\end{array}$ & $\begin{array}{c}1.868 * * * \\
(0.125)\end{array}$ & $\begin{array}{c}1.031^{* * *} \\
(0.133)\end{array}$ \\
\hline Person-Felony & $\begin{array}{c}-0.830^{* * *} \\
(0.169)\end{array}$ & $\begin{array}{c}-0.695^{* *} \\
(0.251)\end{array}$ & $\begin{array}{c}-0.881 * * * \\
(0.229)\end{array}$ \\
\hline Property-Misdemeanor & $\begin{array}{c}2.763 * * * \\
(0.084)\end{array}$ & $\begin{array}{c}3.352 * * * \\
(0.118)\end{array}$ & $\begin{array}{c}1.994 * * * \\
(0.131)\end{array}$ \\
\hline Drug & $\begin{array}{c}1.001^{* * *} \\
(0.089)\end{array}$ & $\begin{array}{c}1.592 * * * \\
(0.127)\end{array}$ & $\begin{array}{l}0.297 * \\
(0.224)\end{array}$ \\
\hline Public Order & $\begin{array}{c}1.890 * * * \\
(0.079)\end{array}$ & $\begin{array}{c}2.424 * * * \\
(0.116)\end{array}$ & $\begin{array}{c}1.293^{* * *} \\
(0.113)\end{array}$ \\
\hline Status & $\begin{array}{c}2.664^{* * *} \\
(0.081)\end{array}$ & $\begin{array}{c}3.201^{* * *} \\
(0.115)\end{array}$ & $\begin{array}{c}1.974 * * * \\
(0.129)\end{array}$ \\
\hline Obstruction of Justice & $\begin{array}{c}-0.571 * * * \\
(0.154)\end{array}$ & $\begin{array}{c}-0.398 \\
(0.238)\end{array}$ & $\begin{array}{c}-0.831 * * * \\
(0.209)\end{array}$ \\
\hline Dependency Petition Filed & $\begin{array}{c}-0.676 * * * \\
(0.105)\end{array}$ & $\begin{array}{c}-0.750^{* * *} \\
(0.119)\end{array}$ & $\begin{array}{c}-0.101 \\
(0.259)\end{array}$ \\
\hline Prior Offenses & $\begin{array}{c}-1.406^{* * *} \\
(0.040)\end{array}$ & $\begin{array}{c}-1.646^{* * *} \\
(0.051)\end{array}$ & $\begin{array}{c}-1.016 * * * \\
(0.066)\end{array}$ \\
\hline Urban County & $\begin{array}{c}0.312^{* *} \\
(0.136)\end{array}$ & --- & --- \\
\hline
\end{tabular}

\footnotetext{
${ }^{a}$ White juveniles and property felony offenses represent the reference category.

${ }^{\mathrm{b}}$ Sample size at the individual-level: 18,927; Chi-square $=1,344.624 ; \mathrm{df}=344$.

' Sample size at the individual-level: 12,463; Chi-square $=592.202 ; \mathrm{df}=213$.

${ }^{\mathrm{d}}$ Sample size at the individual-level: 6,464; Chi-square $=895.174 ; \mathrm{df}=274$.

${ }^{*} \mathrm{p}<.05 ;{ }^{* *} \mathrm{p}<.01 ;{ }^{* * *} \mathrm{p}<.001$. Standard errors in parentheses.
} 
Table 9. HGLM Estimates of Juvenile Detention Outcome

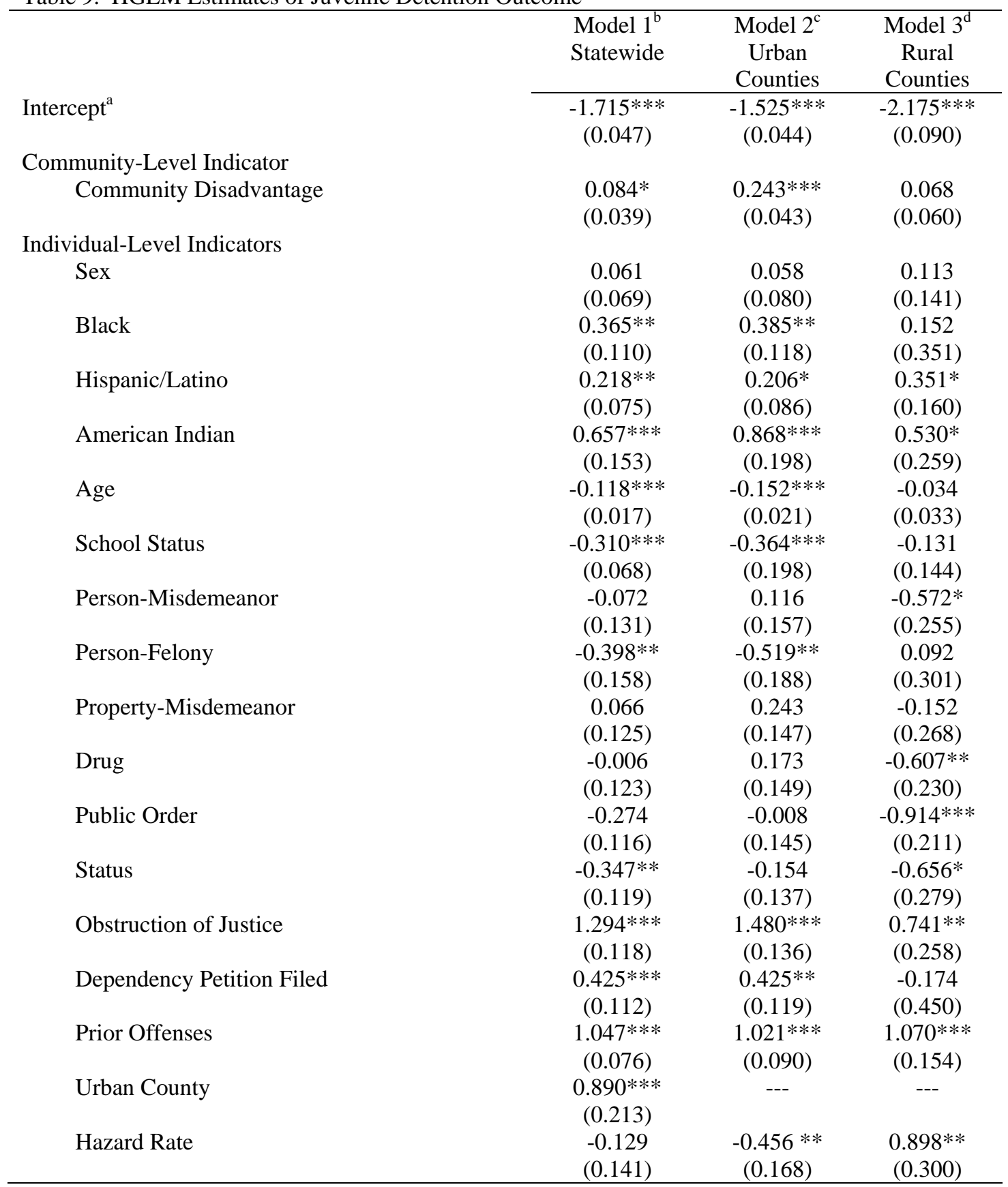

${ }^{\mathrm{a}}$ White juveniles and property felony offenses represent the reference category.

b Sample size at the individual-level: 9,293; Sample size at the community-level: 317; Chi-square = 537.335; $\mathrm{df}=317 .{ }^{\mathrm{c}}$ Sample size at the individual-level: 6,280; Sample size at the communitylevel: 194; Chi-square $=248.669 ; \mathrm{df}=194{ }^{\mathrm{d}}$ Sample size at the individual-level: 2,996; Sample size at the community-level: 233; Chi-square $=312.091 ; \mathrm{df}=233$.

${ }^{*} \mathrm{p}<.05 ;{ }^{* *} \mathrm{p}<.01 ;{ }^{* * *} \mathrm{p}<.001$. Standard errors in parentheses 
Table 10. HGLM Estimates of Juvenile Petition Filed

\begin{tabular}{|c|c|c|c|}
\hline & $\begin{array}{l}\text { Model 1 }{ }^{\mathrm{b}} \\
\text { Statewide }\end{array}$ & $\begin{array}{c}{\text { Model } 2^{\mathrm{C}}}_{\text {Urban }} \\
\text { Counties }\end{array}$ & $\begin{array}{l}{\text { Model } 3^{\mathrm{d}}} \text { Rural } \\
\text { Counties }\end{array}$ \\
\hline Intercept $^{\mathrm{a}}$ & $\begin{array}{c}1.095^{* * *} \\
(0.065)\end{array}$ & $\begin{array}{c}1.355^{* * *} \\
(0.074)\end{array}$ & $\begin{array}{c}0.713^{* * *} \\
(0.099)\end{array}$ \\
\hline \multicolumn{4}{|l|}{ Community-Level Indicator } \\
\hline Community Disadvantage & $\begin{array}{c}0.043 \\
(0.050)\end{array}$ & $\begin{array}{l}0.171^{*} \\
(0.073)\end{array}$ & $\begin{array}{c}0.105 \\
(0.069)\end{array}$ \\
\hline \multicolumn{4}{|l|}{ Individual-Level Indicators } \\
\hline Sex & $\begin{array}{l}0.143^{*} \\
(0.059)\end{array}$ & $\begin{array}{l}0.151^{*} \\
(0.074)\end{array}$ & $\begin{array}{c}0.093 \\
(0.107)\end{array}$ \\
\hline Black & $\begin{array}{l}-0.167 \\
(0.105)\end{array}$ & $\begin{array}{l}-0.206 \\
(0.116)\end{array}$ & $\begin{array}{l}-0.295 \\
(0.281)\end{array}$ \\
\hline Hispanic/Latino & $\begin{array}{c}0.065 \\
(0.067)\end{array}$ & $\begin{array}{c}0.033 \\
(0.082)\end{array}$ & $\begin{array}{c}0.211 \\
(0.129)\end{array}$ \\
\hline American Indian & $\begin{array}{c}0.192 \\
(0.148)\end{array}$ & $\begin{array}{l}-0.025 \\
(0.221)\end{array}$ & $\begin{array}{c}0.468^{* *} \\
(0.218)\end{array}$ \\
\hline Age & $\begin{array}{c}-0.123^{* * *} \\
(0.015)\end{array}$ & $\begin{array}{c}-0.211^{* * *} \\
(0.020)\end{array}$ & $\begin{array}{l}-0.040 \\
(0.024)\end{array}$ \\
\hline School Status & $\begin{array}{c}0.105 \\
(0.059)\end{array}$ & $\begin{array}{l}0.161^{*} \\
(0.075)\end{array}$ & $\begin{array}{c}0.046 \\
(0.110)\end{array}$ \\
\hline Person-Misdemeanor & $\begin{array}{c}-0.798^{* * *} \\
(0.106)\end{array}$ & $\begin{array}{c}-0.612^{* * *} \\
(0.129)\end{array}$ & $\begin{array}{c}-0.949 * * \\
(0.206)\end{array}$ \\
\hline Person-Felony & $\begin{array}{c}-0.182 \\
(0.129)\end{array}$ & $\begin{array}{l}-0.356^{*} \\
(0.152)\end{array}$ & $\begin{array}{l}-0.106 \\
(0.247)\end{array}$ \\
\hline Property-Misdemeanor & $\begin{array}{c}-0.540^{* * *} \\
(0.111)\end{array}$ & $\begin{array}{l}-0.310^{*} \\
(0.133)\end{array}$ & $\begin{array}{c}-1.043 * * * \\
(0.203)\end{array}$ \\
\hline Drug & $\begin{array}{c}-0.355^{* *} \\
(0.102)\end{array}$ & $\begin{array}{l}-0.041 \\
(0.127)\end{array}$ & $\begin{array}{c}-0.856^{*} \\
(0.165)\end{array}$ \\
\hline Public Order & $\begin{array}{c}-0.763^{* * *} \\
(0.091)\end{array}$ & $\begin{array}{c}0.053 \\
(0.117)\end{array}$ & $\begin{array}{c}-2.011 * * * \\
(0.226)\end{array}$ \\
\hline Status & $\begin{array}{c}-0.736^{* * *} \\
(0.101)\end{array}$ & $\begin{array}{l}-0.094 \\
(0.121)\end{array}$ & $\begin{array}{c}-2.630 * * * \\
(0.286)\end{array}$ \\
\hline Obstruction of Justice & $\begin{array}{c}1.838 * * * \\
(0.166)\end{array}$ & $\begin{array}{c}1.779 * * * \\
(0.202)\end{array}$ & $\begin{array}{c}1.151^{* * *} \\
(0.387)\end{array}$ \\
\hline Dependency Petition Filed & $\begin{array}{c}-0.356^{* *} \\
(0.120)\end{array}$ & $\begin{array}{c}-0.383^{* *} \\
(0.129)\end{array}$ & $\begin{array}{l}-0.070 \\
(0.379)\end{array}$ \\
\hline Prior Offenses & $\begin{array}{c}0.210^{* *} \\
(0.060)\end{array}$ & $\begin{array}{c}0.135 \\
(0.074)\end{array}$ & $\begin{array}{c}0.577^{* * *} \\
(0.116)\end{array}$ \\
\hline Urban County & $\begin{array}{c}0.607 * * * \\
(0.161)\end{array}$ & --- & --- \\
\hline Detention & $\begin{array}{c}1.613^{* * *} \\
(0.100)\end{array}$ & $\begin{array}{c}1.818 * * * \\
(0.128)\end{array}$ & $\begin{array}{c}1.216^{* * *} \\
(0.176)\end{array}$ \\
\hline Hazard Rate & $\begin{array}{c}0.699 * * * \\
(0.114)\end{array}$ & $\begin{array}{l}0.183^{*} \\
(0.144)\end{array}$ & $\begin{array}{l}0.582 * \\
(0.232) \\
\end{array}$ \\
\hline
\end{tabular}

${ }^{\mathrm{a}}$ White juveniles and property felony offenses represent the reference category.

${ }^{\text {b }}$ Sample size at the individual-level: 9,312; Sample size at the community-level: 317; Chi-square = 1237.303; $\mathrm{df}=317 .{ }^{\mathrm{c}}$ Sample size at the individual-level: 6,298; Sample size at the community-

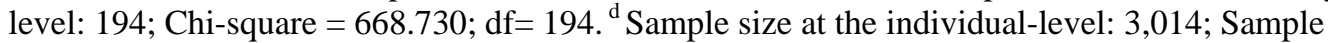
size at the community-level: 233; Chi-square $=579.677 ; \mathrm{df}=233$.

${ }^{*} \mathrm{p}<.05 ;{ }^{* *} \mathrm{p}<.01 ;{ }^{* * *} \mathrm{p}<.001$. Standard errors in parentheses 
Table 11. HGLM Estimates of Judicially Dismissed Petition

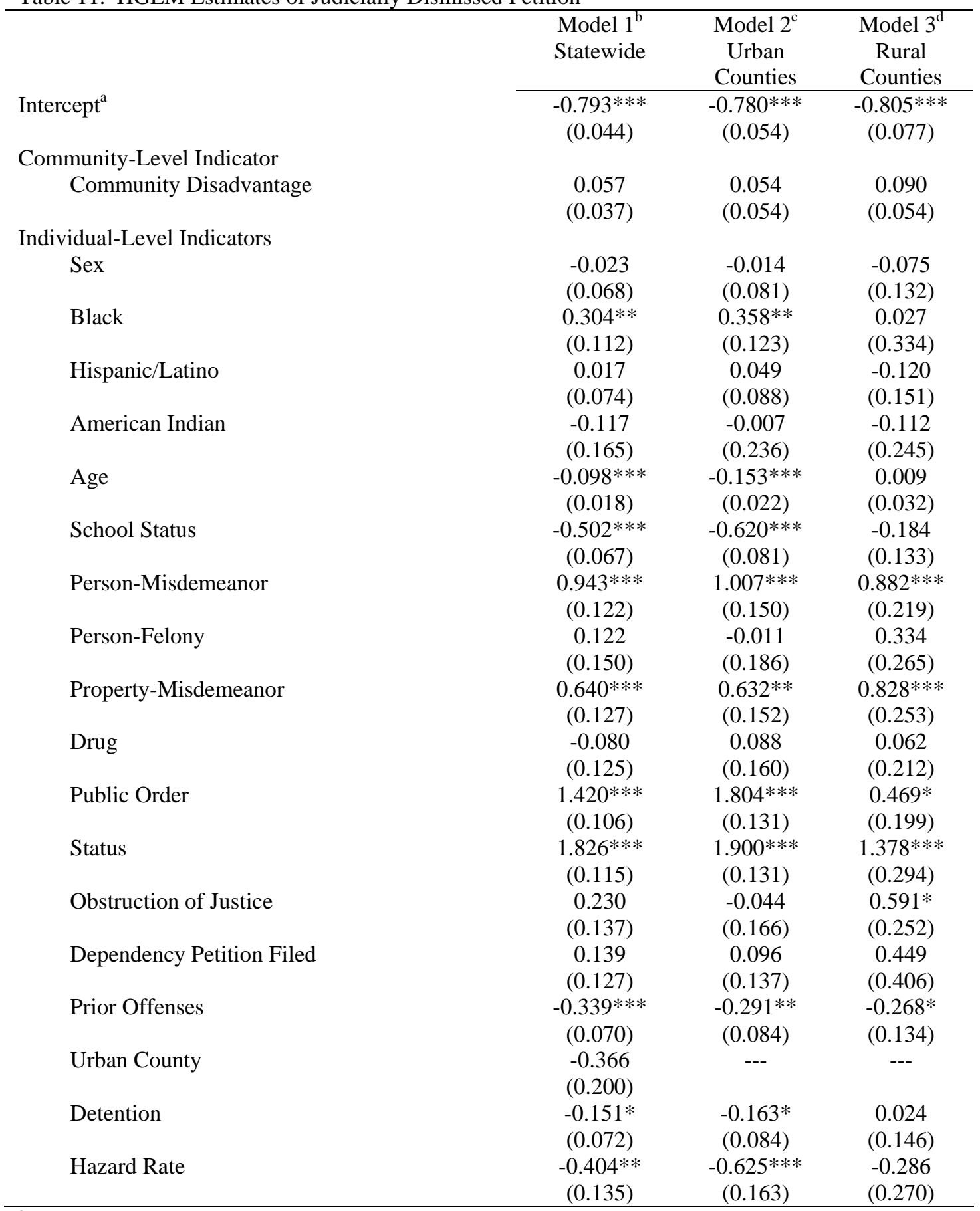

${ }^{\mathrm{a}}$ White juveniles and property felony offenses represent the reference category.

b Sample size at the individual-level: 6,570; Sample size at the community-level: 293; Chi-square $=520.473 ; \mathrm{df}=293 .{ }^{\mathrm{c}}$ Sample size at the individual-level: 4,696; Sample size at the communitylevel: 179; Chi-square = 325.587; $\mathrm{df}=179 .{ }^{\mathrm{d}}$ Sample size at the individual-level: 1,875; Sample size at the community-level: 199; Chi-square = 287.549; $\mathrm{df}=199$.

${ }^{*} \mathrm{p}<.05 ;{ }^{* *} \mathrm{p}<.01 ;{ }^{* * *} \mathrm{p}<.001$. Standard errors in parentheses 
Table 12. HGLM Estimates of Out-of-Home Placement

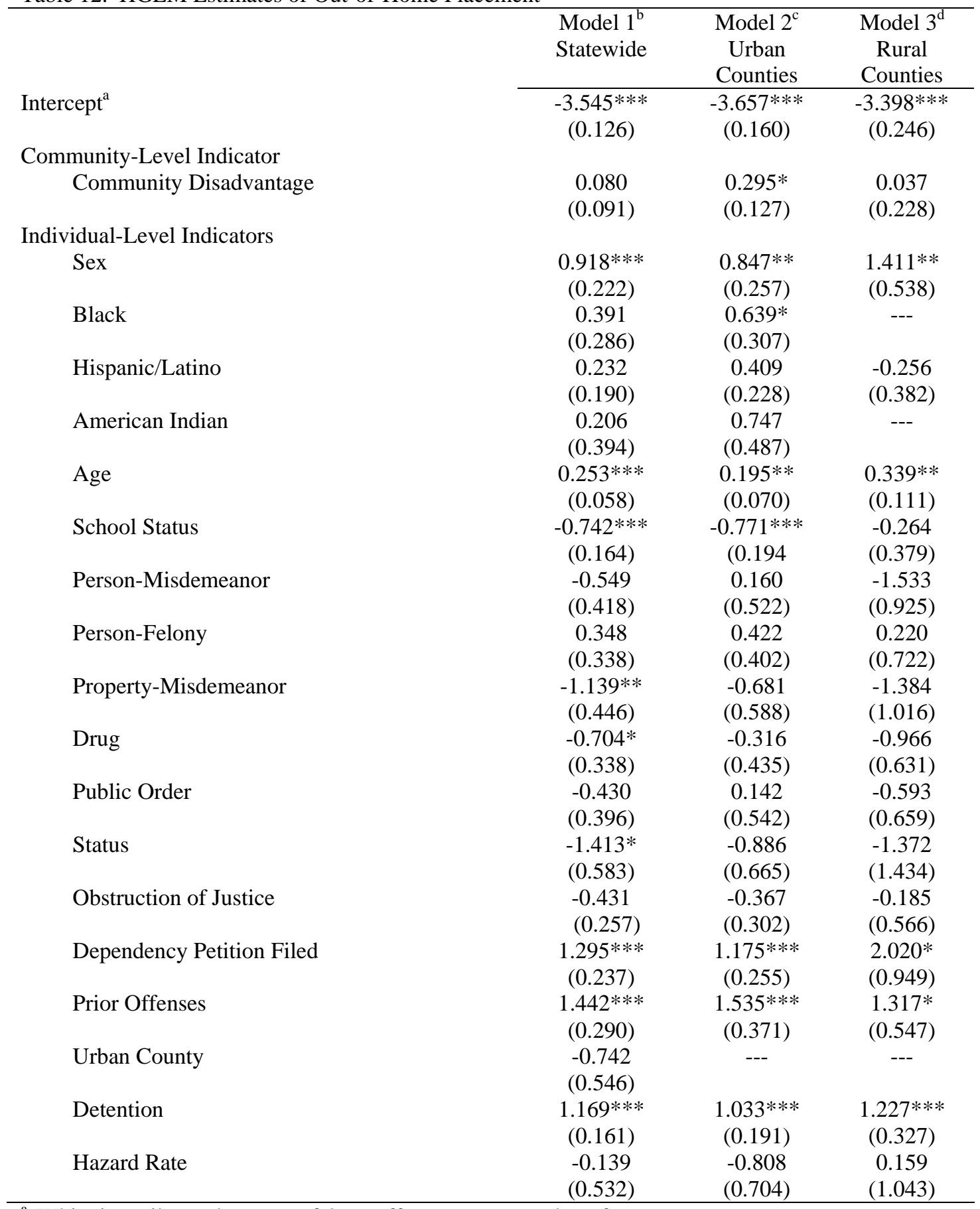

${ }^{\mathrm{a}}$ White juveniles and property felony offenses represent the reference category.

${ }^{\text {b }}$ Sample size at the individual-level: 4,232; Sample size at the community-level: 270; Chi-square $=350.462 ; \mathrm{df}=270 .{ }^{\mathrm{c}}$ Sample size at the individual-level: 2,983; Sample size at the communitylevel: 160 ; Chi-square $=260.155 ; \mathrm{df}=160{ }^{\mathrm{d}}$ Sample size at the individual-level: 1,077: Sample size at the community-level: 140 ; Chi-square $=163.930 ; \mathrm{df}=140$.

${ }^{*} \mathrm{p}<.05 ;{ }^{* *} \mathrm{p}<.01 ;{ }^{* * *} \mathrm{p}<.001$. Standard errors in parentheses 
Table 13. HGLM Estimates of Recidivism Post Age 17 - Informal Procesing as a Predictor

\begin{tabular}{|c|c|c|c|}
\hline & $\begin{array}{l}\text { Model } 1^{\mathrm{b}} \\
\text { Statewide }\end{array}$ & $\begin{array}{c}\text { Model } 2^{\mathrm{C}} \\
\text { Urban } \\
\text { Counties }\end{array}$ & $\begin{array}{c}\text { Model 3 }^{\mathrm{d}} \\
\text { Rural } \\
\text { Counties }\end{array}$ \\
\hline Intercept $^{\mathrm{a}}$ & $\begin{array}{c}-1.317 * * * \\
(0.051)\end{array}$ & $\begin{array}{c}-1.101^{* * *} \\
(0.060)\end{array}$ & $\begin{array}{c}-1.519 * * * \\
(0.077)\end{array}$ \\
\hline $\begin{array}{l}\text { Community-Level Indicator } \\
\text { Community Disadvantage }\end{array}$ & $\begin{array}{c}0.009 \\
(0.039)\end{array}$ & $\begin{array}{c}0.083 \\
(0.059)\end{array}$ & $\begin{array}{c}0.019 \\
(0.052)\end{array}$ \\
\hline $\begin{array}{l}\text { Individual-Level Indicators } \\
\text { Sex }\end{array}$ & $\begin{array}{c}0.965 * * * \\
(0.043)\end{array}$ & $\begin{array}{c}0.977 * * * \\
(0.051)\end{array}$ & $\begin{array}{c}0.915^{* * *} \\
(0.082)\end{array}$ \\
\hline Black & $\begin{array}{c}0.326 * * * \\
(0.075)\end{array}$ & $\begin{array}{c}0.321 * * * \\
(0.082)\end{array}$ & $\begin{array}{c}0.249 \\
(0.201)\end{array}$ \\
\hline Hispanic/Latino & $\begin{array}{c}0.264^{* * *} \\
(0.046)\end{array}$ & $\begin{array}{c}0.244 * * * \\
(0.054\end{array}$ & $\begin{array}{c}0.368 * * * \\
(0.092)\end{array}$ \\
\hline American Indian & $\begin{array}{c}0.507 * * * \\
(0.102)\end{array}$ & $\begin{array}{c}0.583^{* * *} \\
(0.146)\end{array}$ & $\begin{array}{l}0.503 * * \\
(0.146)\end{array}$ \\
\hline Age & $\begin{array}{c}0.158 * * * \\
(0.011)\end{array}$ & $\begin{array}{c}0.144 * * * \\
(0.014)\end{array}$ & $\begin{array}{c}0.179 * * * \\
(0.020)\end{array}$ \\
\hline School Status & $\begin{array}{l}-0.026 \\
(0.043)\end{array}$ & $\begin{array}{l}-0.071 \\
(0.052)\end{array}$ & $\begin{array}{c}0.085 \\
(0.082)\end{array}$ \\
\hline Person-Misdemeanor & $\begin{array}{l}-0.022 \\
(0.085)\end{array}$ & $\begin{array}{l}-0.032 \\
(0.103)\end{array}$ & $\begin{array}{l}-0.054 \\
(0.154)\end{array}$ \\
\hline Person-Felony & $\begin{array}{l}-0.041 \\
(0.112)\end{array}$ & $\begin{array}{c}0.040 \\
(0.131)\end{array}$ & $\begin{array}{l}-0.398 \\
(0.232)\end{array}$ \\
\hline Property-Misdemeanor & $\begin{array}{c}-0.077 \\
(0.078)\end{array}$ & $\begin{array}{c}-0.129 \\
(0.093)\end{array}$ & $\begin{array}{c}-0.091 \\
(0.150)\end{array}$ \\
\hline Drug & $\begin{array}{l}-0.034 \\
(0.082)\end{array}$ & $\begin{array}{l}-0.112 \\
(0.101)\end{array}$ & $\begin{array}{c}0.085 \\
(0.143)\end{array}$ \\
\hline Public Order & $\begin{array}{c}-0.288 * * * \\
(0.072)\end{array}$ & $\begin{array}{c}-0.349 * * * \\
(0.089)\end{array}$ & $\begin{array}{l}-0.243 \\
(0.128)\end{array}$ \\
\hline Status & $\begin{array}{c}0.112 \\
(0.108)\end{array}$ & $\begin{array}{c}-0.264^{* *} \\
(0.090)\end{array}$ & $\begin{array}{c}0.077 \\
(0.145)\end{array}$ \\
\hline Obstruction of Justice & $\begin{array}{c}0.135 \\
(0.088)\end{array}$ & $\begin{array}{c}-0.021 \\
(0.105)\end{array}$ & $\begin{array}{l}0.432 * \\
(0.158)\end{array}$ \\
\hline Dependency Petition Filed & $\begin{array}{c}0.353 * * * \\
(0.094)\end{array}$ & $\begin{array}{c}0.394 * * * \\
(0.100)\end{array}$ & $\begin{array}{l}-0.122 \\
(0.299)\end{array}$ \\
\hline Prior Offenses & $\begin{array}{c}0.764^{* * *} \\
(0.042\end{array}$ & $\begin{array}{c}0.813^{* * *} \\
(0.051\end{array}$ & $\begin{array}{c}0.665^{* * *} \\
(0.076)\end{array}$ \\
\hline Urban County & $\begin{array}{c}0.462^{* *} \\
(0.135)\end{array}$ & --- & --- \\
\hline Informal Processing & $\begin{array}{c}-0.120^{* *} \\
(0.044)\end{array}$ & $\begin{array}{l}-0.106 * \\
(0.054)\end{array}$ & $\begin{array}{c}-0.116 \\
(0.078)\end{array}$ \\
\hline
\end{tabular}

\footnotetext{
${ }^{\mathrm{a}}$ White juveniles and property felony offenses represent the reference category.

${ }^{\text {b }}$ Sample size at the individual-level: 18,927; Sample size at the community-level: 345; Chi-square $=1,717.607 ; \mathrm{df}=343 .{ }^{\mathrm{c}}$ Sample size at the individual-level: 12,463 ; Sample size at the communitylevel: 212; Chi-square $=859.179$; $\mathrm{df}=212 .{ }^{\mathrm{d}}$ Sample size at the individual-level: 6,464; Sample size at the community-level: 273 ; Chi-square $=793.072 ; \mathrm{df}=273$.

${ }^{*} \mathrm{p}<.05 ;{ }^{* *} \mathrm{p}<.01 ;{ }^{* * *} \mathrm{p}<.001$. Standard errors in parentheses
} 
Table 14. HGLM Estimates of Recidivism Post Age 17 - Detention as a Predictor

\begin{tabular}{|c|c|c|c|}
\hline & $\begin{array}{l}\text { Model } 1^{\mathrm{b}} \\
\text { Statewide }\end{array}$ & $\begin{array}{c}\text { Model } 2^{\mathrm{C}} \\
\text { Urban } \\
\text { Counties }\end{array}$ & $\begin{array}{c}\text { Model 3 }^{\mathrm{d}} \\
\text { Rural } \\
\text { Counties }\end{array}$ \\
\hline Intercept $^{\mathrm{a}}$ & $\begin{array}{c}-0.990 * * * \\
(0.059)\end{array}$ & $\begin{array}{l}0.751^{* * *} \\
(0.067)\end{array}$ & $\begin{array}{c}-1.739 * * * \\
(0.115)\end{array}$ \\
\hline $\begin{array}{l}\text { Community-Level Indicator } \\
\text { Community Disadvantage }\end{array}$ & $\begin{array}{l}-0.013 \\
(0.047)\end{array}$ & $\begin{array}{c}0.061 \\
(0.067)\end{array}$ & $\begin{array}{c}0.044 \\
(0.066)\end{array}$ \\
\hline $\begin{array}{l}\text { Individual-Level Indicators } \\
\quad \text { Sex }\end{array}$ & $\begin{array}{c}0.854^{* * *} \\
(0.062)\end{array}$ & $\begin{array}{c}0.854 * * * \\
(0.073)\end{array}$ & $\begin{array}{c}0.834^{* * *} \\
(0.123)\end{array}$ \\
\hline Black & $\begin{array}{c}0.187 \\
(0.098)\end{array}$ & $\begin{array}{c}0.224^{*} \\
(0.105)\end{array}$ & $\begin{array}{c}-0.180 \\
(0.311)\end{array}$ \\
\hline Hispanic/Latino & $\begin{array}{c}0.292 * * * \\
(0.063)\end{array}$ & $\begin{array}{l}0.271 * * * \\
(0.073)\end{array}$ & $\begin{array}{l}0.331^{* *} \\
(0.132)\end{array}$ \\
\hline American Indian & $\begin{array}{c}0.433 * * \\
(0.140)\end{array}$ & $\begin{array}{l}0.598 * * \\
(0.194)\end{array}$ & $\begin{array}{c}0.297 \\
(0.216)\end{array}$ \\
\hline Age & $\begin{array}{c}0.159 * * * \\
(0.015)\end{array}$ & $\begin{array}{c}0.152^{* * *} \\
(0.019)\end{array}$ & $\begin{array}{c}0.156^{* * *} \\
(0.029)\end{array}$ \\
\hline School Status & $\begin{array}{c}-0.076 \\
(0.058)\end{array}$ & $\begin{array}{c}-0.149 * \\
(0.068)\end{array}$ & $\begin{array}{c}0.097 \\
(0.117)\end{array}$ \\
\hline Person-Misdemeanor & $\begin{array}{l}-0.083 \\
(0.102)\end{array}$ & $\begin{array}{l}-0.152 \\
(0.119)\end{array}$ & $\begin{array}{c}0.139 \\
(0.207)\end{array}$ \\
\hline Person-Felony & $\begin{array}{c}0.024 \\
(0.118)\end{array}$ & $\begin{array}{c}0.056 \\
(0.136)\end{array}$ & $\begin{array}{c}-0.102 \\
(0.259)\end{array}$ \\
\hline Property-Misdemeanor & $\begin{array}{l}0.058 \\
(0.104)\end{array}$ & $\begin{array}{c}0.028 \\
(0.120)\end{array}$ & $\begin{array}{c}0.029 \\
(0.230)\end{array}$ \\
\hline Drug & $\begin{array}{c}-0.031 \\
(0.094)\end{array}$ & $\begin{array}{c}-0.145 \\
(0.113)\end{array}$ & $\begin{array}{c}0.320 \\
(0.182)\end{array}$ \\
\hline Public Order & $\begin{array}{l}-0.296 * \\
(0.085)\end{array}$ & $\begin{array}{c}-0.350^{* *} \\
(0.134)\end{array}$ & $\begin{array}{l}-0.108 \\
(0.169)\end{array}$ \\
\hline Status & $\begin{array}{c}-0.240 * \\
(0.099)\end{array}$ & $\begin{array}{c}-0.337 * * \\
(0.111)\end{array}$ & $\begin{array}{c}0.191 \\
(0.230)\end{array}$ \\
\hline Obstruction of Justice & $\begin{array}{l}-0.018 \\
(0.097)\end{array}$ & $\begin{array}{l}-0.202 \\
(0.144)\end{array}$ & $\begin{array}{l}0.514 * * \\
(0.198)\end{array}$ \\
\hline Dependency Petition Filed & $\begin{array}{c}0.278^{*} \\
(0.109)\end{array}$ & $\begin{array}{c}0.340^{* *} \\
(0.115)\end{array}$ & $\begin{array}{c}-0.569 \\
(0.403)\end{array}$ \\
\hline Prior Offenses & $\begin{array}{c}0.800 * * * \\
(0.059)\end{array}$ & $\begin{array}{c}0.806 * * * \\
(0.069)\end{array}$ & $\begin{array}{c}0.825^{* * *} \\
(0.116)\end{array}$ \\
\hline Urban County & $\begin{array}{c}0.395 * \\
(0.166)\end{array}$ & --- & --- \\
\hline Detention & $\begin{array}{c}0.448 * * * \\
(0.064)\end{array}$ & $\begin{array}{c}0.474 * * * \\
(0.074)\end{array}$ & $\begin{array}{c}0.411^{* *} \\
(0.134)\end{array}$ \\
\hline
\end{tabular}

\footnotetext{
${ }^{\mathrm{a}}$ White juveniles and property felony offenses represent the reference category.

b Sample size at the individual-level: 9,312; Sample size at the community-level: 317; Chi-square $=1,207.225 ; \mathrm{df}=317$. ${ }^{\mathrm{c}}$ Sample size at the individual-level: 6,298; Sample size at the community-

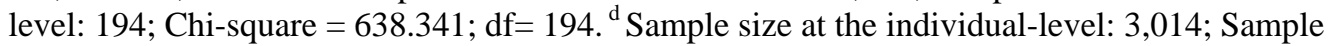
size at the community-level: 233 ; Chi-square $=528.180 ; \mathrm{df}=233$. ${ }^{*} \mathrm{p}<.05 ;{ }^{* *} \mathrm{p}<.01 ;{ }^{* * *} \mathrm{p}<.001$. Standard errors in parentheses
} 